\title{
STEPHen Rose
}

Email: stephen.rose@rhul.ac.uk

\section{PROTECTED PUBLICATIONS: THE IMPERIAL AND SAXON PRIVILEGES FOR PRINTED MUSIC, 1550-1700}

In the decades around 1600 many privileges for printed music were issued by the Holy Roman Emperor and the Elector of Saxony. Such privileges gave a bookseller or author an exclusive right to publish specified works for a limited period (usually ten years). The privileges threatened confiscation of any unauthorised copies, and fines for anyone caught printing or selling them. This article offers the first systematic study of archival material documenting the privileges for music, as preserved in the Österreichisches Staatsarchiv, Vienna, and the Sächsisches Hauptstaatsarchiv, Dresden. It reconstructs the ritualistic procedure for obtaining a privilege, analyses how composers justified their applications for privileges, and asks whether privileges gave effective protection against unauthorised editions. Revising previous interpretations of the privilege system as an early form of copyright, I instead argue that privileges enhanced the commercial and symbolic value of printed music.

Printed music around 1600 in German-speaking lands was partly a product of early capitalism, and partly a symbol of authority, prestige and skill. On the one hand, John Kmetz has interpreted sixteenthcentury music publishers as business people who took the risk of producing multiple copies and sought to recoup their investment

I am grateful to Christa Maria Richter for her assistance in searching and scanning documents in the Sächsisches Hauptstaatsarchiv; and I thank Frau Richter, Matthew Laube and Bernd Koska for checking my transcriptions of archival documents. I am also grateful to Tim Carter, Elisabeth Giselbrecht, Iain Fenlon, Gregory Johnston, Walter Werbeck, Peter Wollny and the anonymous referees for their advice and comments.

The following library sigla are used in this article:

A-Wsta Vienna, Österreichisches Staatsarchiv, Haus-, Hof- und Staatsarchiv

D-Dla Dresden, Sächsisches Hauptstaatsarchiv

D-LEsm Leipzig, Stadtgeschichtliches Museum

D-Mbs Munich, Bayerische Staatsbibliothek

D-W Wolfenbüttel, Herzog August Bibliothek

GB-Lbl London, British Library

PL-Kj Kraków, Biblioteka Jagiellońska 


\section{Stephen Rose}

through sales. ${ }^{1}$ On the other hand, much printed music held symbolic meanings for composers, dedicatees and owners; such books might circulate in a gift economy, being offered in the expectation of a reward. ${ }^{2}$ These dual functions are encapsulated in Royston Gustavson's notion that every stage in the printing of a music book was intended to create value, whether financial profit or an enhanced reputation; ${ }^{3}$ they also reflect the tension in the period between early capitalism and older ideals of serving the common good. ${ }^{4}$ Yet scholars can struggle to locate specific items of printed music on this spectrum between commercial and symbolic value. Generally all that survives are the printed books themselves; only rarely is there archival evidence of how a music book was funded or how well it sold.

Some light, however, can be shed on the commercial and symbolic functions of printed music via the privileges granted for such publications. These privileges were favours conferred by rulers such as the Holy Roman Emperor or the Elector of Saxony, giving a bookseller or author an exclusive right to publish specified works for a limited period (usually ten years). The privilege threatened confiscation of unauthorised copies, and fines for anyone caught printing or selling them. Unlike the patent for music printing in late Tudor England, privileges in German lands were not monopolies over the entire trade; nor did they confer rights involving the import of books or sale of printed music paper. ${ }^{5}$ In many cases, imperial or Saxon privileges protected a publisher's or composer's investment in a specific edition, and may indicate genres or authors in commercial demand. Other privileges, however, were marks of prestige, granting an edition some of the authority of the Holy Roman Emperor or the Elector of Saxony.

Hundreds of music books from the decades around 1600 indicate on the title page that they were protected by a privilege, using such

${ }^{1}$ J. Kmetz, '250 Years of German Music Printing (c. 1500-1750): A Case for a Closed Market', in B. Lodes (ed.), NiveauNischeNimbus: Die Anfänge des Musikdrucks nördlich der Alpen (Tutzing, 2010), pp. 167-85.

${ }^{2}$ On printed music as a gift, see S. Rose, 'The Mechanisms of the Music Trade in Central Germany, 1600-1640', Journal of the Royal Musical Association, 130 (2005), pp. 1-37, at pp. 24-32.

3 R. Gustavson, 'Competitive Strategy Dynamics in the German Music Publishing Industry 1530-1550', in Lodes (ed.), NiveauNischeNimbus, pp. 185-210, at p. 186.

4 On these tensions in Luther's writings, see W. J. Wright, Capitalism, the State, and the Lutheran Reformation: Sixteenth-Century Hesse (Athens, Ohio, 1988), pp. 15-23.

${ }^{5}$ On the patent for printed music held by William Byrd and Thomas Tallis, see I. Fenlon and J. Milsom, "Ruled Paper Imprinted": Music Paper and Patents in Sixteenth-Century England', Journal of the American Musicological Society, 37 (1984), pp. 139-63; also T. Tallis and W. Byrd, Cantiones sacrae 1575, ed. J. Milsom, Early English Church Music, 56 (London, 2014), pp. xxvii-xxx. 


\section{Protected Publications}

rubrics as 'Cum gratia et privilegio' or 'Mit churfürstlicher Befreyhung'. Yet such statements rarely reveal who held the privilege or its duration. Nor do they give any information about how privileges were granted and whether they were enforced. Furthermore these rubrics cannot always be taken at face value: an imperial edict of 1608 complained that some books falsely claimed on their title pages to hold a privilege. ${ }^{6}$

More informative are the surviving archival records, including application letters and the drafts and fair copies of the privileges themselves. These documents show the legal justifications for privileges, illuminating the relationship between composers and princely authority. In 1962 a selection of these documents was transcribed and published by the legal historian Hansjörg Pohlmann, whose monograph was until now the main study of privileges for music. ${ }^{7}$ Unfortunately, Pohlmann's work is flawed by his limited awareness of publishing practices in the period, and by his teleological interpretation of privileges as anticipations of the modern copyright system. He declared these legal instruments were 'rights of protection for creators, a formal confirmation of the exclusive publication rights of authors already won by virtue of their creative work, for the purpose of faster, more effective enforcement against copyright infringements' ${ }^{8}$ In his analysis of privilege documents, Pohlmann highlighted phrases that apparently anticipated later notions of an author's economic rights (the right to profit from a work) and moral rights (the right to have the author's name associated with the work). ${ }^{9}$ He even compared the 'Cum gratia et privilegio' rubric on a title page with the (c) sign. ${ }^{10}$ Such an anachronistic viewpoint, however, obscured the fundamental characteristic of privileges as exceptional favours granted by a prince, rather than inherent rights held by all authors. Moreover, Pohlmann's focus on composers as creators overlooked the fact that privileges were mainly given to those who had invested financially in a book, including authors who published their own works.

${ }^{6}$ W. Brückner, 'Eine Messbuchhändlerliste von 1579 und Beiträge zur Geschichte der Bücherkommission', Archiv für Geschichte des Buchwesens, 3 (1961), cols. 1629-48, at col. 1644.

${ }^{7}$ H. Pohlmann, Die Frühgeschichte des musikalischen Urheberrechts (ca.1400-1800): Neue Materialien zur Entwicklung des Urheberrechtsbewußtseins der Komponisten (Kassel, 1962).

8 'Urheber-Schutzrechte, die eine formelle Bestätigung des schon kraft Werkschöpfung gewonnenen ausschließlichen Veröffentlichungsrechts des Autoren zwecks schnellerer, wirksamerer Vollstreckung bei Urheberrechtsverletzungen waren.' Ibid., p. 189.

9 Ibid., pp. 212-13.

${ }^{10}$ Ibid., p. 190. 


\section{Stephen Rose}

This article offers the first systematic study of archival records for printing privileges relating to music, as issued by the Holy Roman Emperor and the Elector of Saxony between 1550 and 1700. Part of the article draws on documents in the Österreichisches Staatsarchiv, Vienna, guided by the catalogue of the Impressorialakten compiled by Hans-Joachim Koppitz, who identified (but did not comment upon) many sources unavailable to Pohlmann. ${ }^{11}$ The greater part of the article, however, is based on a thorough search of uncatalogued documents in the Sächsisches Hauptstaatsarchiv, Dresden, including many previously unknown letters from composers of the early seventeenth century. Although the archival records in both Vienna and Dresden are incomplete - covering only a fraction of the books that list privileges on their title pages - they reveal many of the negotiations involved in publishing a music book. They also allow a closer understanding of the relationship between the symbolic and commercial aspects of the music trade.

This article is a pendant to a book-length study of musical authorship which examines the discourses of ownership used by Lutheran composers in the seventeenth century. ${ }^{12}$ Here I analyse my archival discoveries to reconstruct the workings of the privilege system and its implications for the music trade of the period. The article begins by categorising the composers and musical genres that are known to have received privileges; it also introduces the types and terms of privileges usually encountered. I interpret the application process for privileges as a symbolic performance of princely power, in which the applicants had to submit to the absolute authority of the ruler. In my analysis of composers' petitions for privileges, I replace Pohlmann's teleological interpretations with more historically nuanced notions of authorship, showing how musicians sought remuneration for the labour and capital they invested in their publications. The archival records documenting privileges also illuminate the costs faced by composers who published their own music, and the role of intermediaries including women in the making of posthumous editions. Finally, the article considers whether privileges offered effective protection against unauthorised editions, with reference to Heinrich Schütz, Johann Hermann Schein and Heinrich Albert. The appendices present transcriptions and translations of a selection of newly

${ }^{11}$ H.-J. Koppitz, Die kaiserlichen Druckprivilegien im Haus-, Hof- und Staatsarchiv Wien: Verzeichnis der Akten vom Anfang des 16. Jahrhunderts bis zum Ende des Deutschen Reichs (1806) (Wiesbaden, 2008). Some privileges are recorded instead in the Reichsregister.

12 S. Rose, Musical Authorship from Schütz to Bach (Cambridge, forthcoming 2019). 


\section{Protected Publications}

discovered documents, including petitions from Seth Calvisius, Andreas Hammerschmidt, Michael Praetorius and Schein.

\section{PRIVILEGES FOR PRINTED MUSIC}

In the mosaic of jurisdictions over German-speaking lands in the early seventeenth century, printing privileges were most frequently granted by the Holy Roman Emperor or the Elector of Saxony. ${ }^{13}$ An imperial privilege was valid throughout the Holy Roman Empire, but had particular relevance to the twice-yearly book fair at Frankfurt am Main, which was regulated by the imperial book commission. The commission had powers to confiscate any book sold at the Frankfurt fair that infringed an imperial privilege, and it required booksellers at the fair to display any imperial privileges they held. ${ }^{14}$ A Saxon privilege was valid solely within Electoral Saxony, but gave protection against unauthorised copies at the Leipzig book fair, which was regulated by the Saxon book commission under the command of the Elector. ${ }^{15}$ Consequently Saxon privileges were mainly obtained by publishers and authors from Dresden, Leipzig and Wittenberg, but also sometimes by figures from further afield. Privileges could be obtained in other territories such as Electoral Brandenburg, ${ }^{16}$ but these were generally less sought after because they did not hold jurisdiction over the book fairs.

Table 1 shows musicians active in German-speaking lands between 1550 and 1700 who held imperial printing privileges, as documented by material surviving in the Österreichisches Staatsarchiv and selected other archives; Table 2 shows publishers who held imperial printing privileges specifically for music. Of the composers with privileges, some were internationally famous and their publications circulated across and beyond the Empire - notably Orlande de Lassus, who had the unusual

13 Overviews of printing privileges include I. Maclean, Scholarship, Commerce, Religion: The Learned Book in the Age of Confessions, 1560-1630 (Cambridge, Mass., 2012), pp. 134-51; L. Gieseke, Vom Privileg zum Urheberrecht: Die Entwicklung des Urheberrechts in Deutschland bis 1845 (Göttingen, 1995); H.-J. Koppitz, 'Die Privilegia impressoria des Haus-, Hof- und Staatsarchivs in Wien', Gutenberg-Jahrbuch, 69 (1994), pp. 187-207; F. Lehne, 'Zur Rechtsgeschichte der kaiserlichen Privilegien', Mitteilungen des österreichischen Instituts für Geschichtsforschung, 53 (1939), pp. 323-409.

${ }^{14}$ Maclean, Scholarship, Commerce, Religion, pp. 137-9.

${ }^{15}$ See electoral rescripts of 13 May 1620 and 7 Nov. 1636 in Codex Augusteus, oder neuvermehrtes Corpus Juris Saxonici (Leipzig, 1724), i, cols. 409-12.

${ }^{16}$ Brandenburg privileges are stated on the title pages of several music books published in that territory, including Johannes Crüger's Meditationum musicarum Paradisus secundus, oder Ander Musicalisches Lust-Gärtlein, neuer Deutschen Magnificat (Berlin, 1626), RISM A/I C4568, and Heinrich Albert's Arien from 1642 onwards (see discussion of Albert below). 
Table 1 Composers who held imperial printing privileges 1550-1700, where archival evidence survives

\begin{tabular}{|c|c|c|c|c|}
\hline Composer & $\begin{array}{l}\text { Date of } \\
\text { privilege }\end{array}$ & Duration & $\begin{array}{l}\text { Archival evidence (A-Wsa Impressoria } \\
\text { except where stated) }\end{array}$ & $\begin{array}{l}\text { Extant publications that mention } \\
\text { privilege }\end{array}$ \\
\hline $\begin{array}{l}\text { ALBERT, Heinrich } \\
\quad(1604-51)\end{array}$ & 26 Oct. 1648 & 12 years & $\begin{array}{l}\text { Karton } 1 \text {, no. } 7 \text {, fols. } 25^{\mathrm{r}}-26^{\mathrm{v}} \text { (draft } \\
\text { privilege) }\end{array}$ & $\begin{array}{l}\text { Achter Theil der Arien (Königsberg, 1650), } \\
\text { RISM A/I A639 }\end{array}$ \\
\hline $\begin{array}{l}\text { BAKFARK, } \\
\text { Valentin (d. } \\
\text { 1576) }\end{array}$ & 16 July 1565 & 12 years & $\begin{array}{l}\text { Karton } 3 \text {, no. } 4 \text {, fols. } 11^{\mathrm{r}}-12^{\mathrm{v}} \text { (draft } \\
\text { privilege) }\end{array}$ & $\begin{array}{l}\text { Harmoniarum musicarum (Kraków, } \\
\text { 1565), RISM B/I } 1565^{22}\end{array}$ \\
\hline $\begin{array}{l}\text { BOLLIUS, Daniel } \\
\quad(c .1590-c .1638) \\
\text { and his father } \\
\text { Marcus Bollius }\end{array}$ & $\begin{array}{l}23 \text { Sept. } 1614 \\
\quad \text { (date of } \\
\text { application) }\end{array}$ & 5 years & $\begin{array}{l}\text { Karton } 7 \text {, no. 26, fols. 198r-202v (two } \\
\text { identical requests for general } \\
\text { privilege, one signed by Marcus } \\
\text { Bollius, one by Daniel Bollius) }\end{array}$ & No surviving printed music \\
\hline $\begin{array}{l}\text { HANDL [Gallus], } \\
\text { Jacobus } \\
(1550-91)\end{array}$ & 19 Mar. 1588 & 6 years & $\begin{array}{l}\text { Karton } 27, \text { no. } 46, \text { fols. } 481^{\mathrm{r}}-482^{\mathrm{v}} \\
\quad(\text { draft privilege })\end{array}$ & $\begin{array}{l}\text { Quartus tomus musici operis harmoniarum } \\
\text { (Prague, 1590) (includes extract } \\
\text { from privilege), RISM A/I H1985 }\end{array}$ \\
\hline $\begin{array}{l}\text { HASSLER, Hans } \\
\text { Leo (1564-1612) }\end{array}$ & 8 Apr. 1591 & 10 years & $\begin{array}{l}\text { Karton } 28, \text { no. } 20 \text {, fols. } 136^{\mathrm{r}}-139^{\mathrm{v}} \\
\quad \text { (petition and draft privilege) }\end{array}$ & $\begin{array}{l}\text { Cantiones sacrae (Augsburg, 1591); Neüe } \\
\text { teütsche Gesang (Augsburg, 1596); } \\
\text { Cantiones sacrae, 2nd edn } \\
\text { (Nuremberg, 1597); Missae quaternis } \\
\text { (Nuremberg, 1599); Sacri concentus } \\
\text { (Augsburg, 1601), RISM A/I } \\
\text { H2323-4, 2327-8, } 2336\end{array}$ \\
\hline $\begin{array}{l}\text { HEIDE, Tobias von } \\
\text { der }\end{array}$ & 7 Feb. 1562 & 10 years & $\begin{array}{l}\text { Karton } 28, \text { no. } 35 \text {, fols. } 241^{\mathrm{r}}-244^{\mathrm{v}} \\
\quad \text { (petition and draft privilege) }\end{array}$ & No printed compositions survive \\
\hline
\end{tabular}


Table 1 (Continued)

\begin{tabular}{|c|c|c|c|c|}
\hline Composer & $\begin{array}{l}\text { Date of } \\
\text { privilege }\end{array}$ & Duration & $\begin{array}{l}\text { Archival evidence (A-Wsa Impressoria } \\
\text { except where stated) }\end{array}$ & $\begin{array}{l}\text { Extant publications that mention } \\
\text { privilege }\end{array}$ \\
\hline $\begin{array}{l}\text { JOANELLUS, } \\
\text { Petrus } \\
\text { (Giovanelli, } \\
\text { Pietro) }\end{array}$ & 6 July 1565 & 10 years & $\begin{array}{l}\text { Karton } 34 \text {, no. } 18 \text {, fols. } 156^{\mathrm{r}}-159^{\mathrm{v}} \text { (draft } \\
\quad \text { privilege) }\end{array}$ & $\begin{array}{l}\text { Novi thesauri musici, books 1-5 (Venice, } \\
\text { 1568), RISM B/I 1568 }-1568^{6}\end{array}$ \\
\hline $\begin{array}{l}\text { KNÖFEL, Johann } \\
\text { (d. before } 1600 \text { ) }\end{array}$ & 12 May 1600 & 10 years & $\begin{array}{l}\text { Karton } 29, \text { no. } 57 \text {, fols. } 423^{\mathrm{r}}-425^{\mathrm{v}} \text {. } \\
\text { Draft privilege and application by } \\
\text { Matthias Herr for posthumous } \\
\text { publication of Knöfel's works }\end{array}$ & No extant printed works after 1600 \\
\hline $\begin{array}{r}\text { KRAF, Michael } \\
(1595-1662)\end{array}$ & $\begin{array}{l}\text { Undated } \\
\text { (application } \\
\text { only) }\end{array}$ & $\begin{array}{l}\text { Requested } \\
10 \text { years }\end{array}$ & $\begin{array}{l}\text { Karton } 38, \text { no. } 58 \text {, fols. } 485^{\mathrm{r}}-486^{\mathrm{v}} \\
\quad \text { (application) }\end{array}$ & $\begin{array}{l}\text { Missae senis, octonis, duodenis vocibus } \\
\text { (Ravensburg, 1623); Liber secundus } \\
\text { sacrorum concentuum (Ravensburg, } \\
\text { 1624); Motectae (Ravensburg, 1626); } \\
\text { Sacri litaniarum concentus } \\
\text { (Ravensburg, 1627), RISM A/I } \\
\text { K1887-90 }\end{array}$ \\
\hline $\begin{array}{l}\text { LASSUS, Orlande } \\
\text { de }(1530 / 32-94)\end{array}$ & 15 June 1581 & Perpetual & $\begin{array}{l}\text { Application with supporting letter by } \\
\text { Wilhelm V of Bavaria, in Musée royal } \\
\text { de Mariemont, Inv. Aut. 1112/4 }\end{array}$ & $\begin{array}{l}\text { Extract from privilege in Teutsche Lieder } \\
\text { mit fünff Stimmen (Nuremberg, 1583) } \\
\text { and Newe Teutsche vnnd etliche } \\
\text { Frantzösische Gesäng mit sechs Stimmen } \\
\text { (Munich, 1590), RISM A/I L947, } 996\end{array}$ \\
\hline $\begin{array}{l}\text { NEUSIDLER, } \\
\text { Melchior } \\
(1531-90)\end{array}$ & 16 July 1559 & 10 years & $\begin{array}{l}\text { Karton } 52 \text {, no. } 21 \text {, fols. } 216^{\mathrm{r}}-217^{\mathrm{v}} \text { (draft } \\
\text { privilege) }\end{array}$ & $\begin{array}{l}\text { Teütsch Lautenbuch (Strasbourg, 1574), } \\
\text { RISM } 1574^{13}\end{array}$ \\
\hline
\end{tabular}


Table 1 (Continued)

\begin{tabular}{|c|c|c|c|c|}
\hline Composer & $\begin{array}{l}\text { Date of } \\
\text { privilege }\end{array}$ & Duration & $\begin{array}{l}\text { Archival evidence (A-Wsa Impressoria } \\
\text { except where stated) }\end{array}$ & $\begin{array}{l}\text { Extant publications that mention } \\
\text { privilege }\end{array}$ \\
\hline
\end{tabular}

ROBERTI, Johann 6 June 162810 years Karton 60 , no. 1, fols. $1^{\mathrm{r}}-6^{\mathrm{r}}$ (draft $\quad$ No printed compositions survive

Christoph

$\begin{array}{cc} & \text { SALES, Franz } \\ & (c .1540-99) \\ & \\ & \\ \text { S } & \\ & \\ & \text { SCHOP, Johann } \\ & (\text { d. 1667) }\end{array}$

privilege and application, for

Roberti's compositions and those of his father Heinrich)

12 Dec. 164010 years

$$
\text { and } 24 \text { Nov. each }
$$

9 Mar. 1651

SCHÜTZ, Heinrich 3 Apr. 1637 (1585-1672)
Requested Karton 64, Konvolut 1, no. 7, fols.

10 years $\quad 35^{\mathrm{r}}-38^{\mathrm{v}}$ (application dated $17 \mathrm{Feb}$. 1651)

5 years Karton 61, Konvolut 1, no. 3 (draft privilege)
Karton 61, Konvolut 1, nos. 1-2, fols. $1^{\mathrm{r}}-8^{\mathrm{v}}$ (draft privileges and application)

Sacrarum cantionum, omnis generis instrumentis musicis (Prague, 1593), Officiorum missalium . . liber secundus (Prague, 1594), Officiorum missalium ... liber tertius (Prague, 1596), RISM A/I S394, 395, 397

Karton 64, Konvolut 1, no. 6, fols. 25 ${ }^{\mathrm{r}}$ - Erster Theil Geistlicher Concerten $26^{\mathrm{v}}$ (draft privilege); Karton 64 , Konvolut 1, no. 7, fols. $27^{\mathrm{r}}-34^{\mathrm{v}}$

(Hamburg, 1643-4), RISM A/I S2069 (application dated 17 Jan. 1640); Karton 65, Konvolut 2, no. 12, fols. $182^{\mathrm{r}}-183^{\mathrm{v}}$ (application dated Sept. 1638)

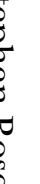

Anderer Theil Kleiner geistlichen Concerten (Dresden, 1639), RISM A/I S2291 
Table 1 (Continued)

\begin{tabular}{|c|c|c|c|c|}
\hline Composer & $\begin{array}{l}\text { Date of } \\
\text { privilege }\end{array}$ & Duration & $\begin{array}{l}\text { Archival evidence (A-Wsa Impressoria } \\
\text { except where stated) }\end{array}$ & $\begin{array}{l}\text { Extant publications that mention } \\
\text { privilege }\end{array}$ \\
\hline & 8 Aug. 1642 & 10 years & $\begin{array}{l}\text { Karton } 61 \text {, Konvolut } 1 \text {, no. } 3 \text { (draft } \\
\text { privilege and Schütz's application, } 25 \\
\text { Apr. 1642) }\end{array}$ & $\begin{array}{l}\text { Symphoniarum sacrarum secunda pars } \\
\text { (Dresden, 1647), Symphoniarum } \\
\text { sacrarum tertia pars (Dresden, 1650), } \\
\text { RISM A/I S2292, } 2295\end{array}$ \\
\hline $\begin{array}{l}\text { STRAUSS, } \\
\quad \text { Christoph } \\
\text { (c. 1575-1631) }\end{array}$ & 5 May 1613 & 10 years & $\begin{array}{l}\text { Karton } 69 \text {, Konvolut } 1 \text {, no. } 25 \text {, fols. } 166^{\mathrm{r}}- \\
167^{\mathrm{v}} \text { (undated application) }\end{array}$ & $\begin{array}{l}\text { Nova ac diversi moda sacrarum cantionum } \\
\text { compositio (Vienna, 1613), RISM A/I } \\
\text { S6935 (with extract of privilege) }\end{array}$ \\
\hline $\begin{array}{l}\text { WEISSENHAN } \\
\text { (Weisshahn), } \\
\text { Adolph }\end{array}$ & 4 Jan. 1604 & 5 years & $\begin{array}{l}\text { Karton } 77 \text {, no. } 19 \text {, fols. } 186^{\mathrm{r}}-7^{\mathrm{v}} \text { (draft } \\
\text { privilege) }\end{array}$ & $\begin{array}{l}\text { No printed works are known to survive. } \\
\text { A theorbist by this name was } \\
\text { employed at the Dresden court in } \\
\text { 1617; see G. S. Johnston, A Heinrich } \\
\text { Schütz Reader (New York, 2013), p. } 15 .\end{array}$ \\
\hline
\end{tabular}


Table 2 Publishers who held imperial printing privileges for musical items 1550-1700, as documented by evidence in Österreichisches Staatsarchiv

\begin{tabular}{|c|c|c|c|c|c|}
\hline Composer/editor & Publisher (place) & $\begin{array}{l}\text { Date of } \\
\text { privilege }\end{array}$ & Duration & $\begin{array}{l}\text { Archival evidence } \\
\text { (A-Wsa Impressoria) }\end{array}$ & Works specified in privilege \\
\hline \multirow[t]{2}{*}{$\begin{array}{l}\text { PRAETORIUS, } \\
\text { Hieronymus } \\
(1560-1629)\end{array}$} & $\begin{array}{l}\text { Philipp de Ohr } \\
\text { (Hamburg) }\end{array}$ & $\begin{array}{l}20 \text { Aug. } \\
1603\end{array}$ & 5 years & $\begin{array}{l}\text { Karton } 21 \text {, no. } 32, \text { fols. } \\
231^{\mathrm{r}}-232^{\mathrm{v}} \text { (draft } \\
\text { privilege) }\end{array}$ & $\begin{array}{l}\text { Cantiones sacrae de festis praecipuis totius } \\
\text { anni (Hamburg, 1607), RISM A/I } \\
\text { P5337 }\end{array}$ \\
\hline & $\begin{array}{l}\text { Georg Ludwig } \\
\text { Frobenius } \\
\text { (Hamburg) }\end{array}$ & $\begin{array}{l}23 \text { Aug. } \\
1616\end{array}$ & unspecified & $\begin{array}{l}\text { Karton } 21, \text { no. } 38 \text {, fols. } \\
252^{\mathrm{r}}-253^{\mathrm{v}} \text { (draft } \\
\text { privilege) }\end{array}$ & $\begin{array}{l}\text { Liber missarum, qui est operum musicorum } \\
\text { tomus tertius, V. VI. VIII. voc. (Hamburg, } \\
\text { 1616), RISM A/I P5329 }\end{array}$ \\
\hline $\begin{array}{l}\text { VINCENTIUS, } \\
\text { Caspar } \\
\text { (c. 1580-1624) }\end{array}$ & $\begin{array}{l}\text { Johann Volmar } \\
\text { (Würzburg) }\end{array}$ & $\begin{array}{r}15 \text { Feb. } \\
1624\end{array}$ & 10 years & $\begin{array}{l}\text { Karton } 74, \text { no. } 63 \text {, fols. } \\
288^{\mathrm{r}}-289^{\mathrm{v}} \\
\text { (application) }\end{array}$ & $\begin{array}{l}\text { In magni illius magni boiariae ducis } \\
\text { symphoniarchae Orlandi de Lasso } \\
\text { Magnum opus musicum Bassus } \\
\text { ad organum nova methodo dispositus } \\
\text { studio et opera Gasparis Vincentii } \\
\text { (Würzburg, 1625), RISM A/I L1033, } \\
\text { VV1648 II,1 (contains Latin extract of } \\
\text { privilege) }\end{array}$ \\
\hline $\begin{array}{l}\text { ZIANI, Pietro Andrea } \\
\text { [Andrea] } \\
\text { (1616-84) }\end{array}$ & $\begin{array}{l}\text { Georg Beuther } \\
\text { (Freiberg) }\end{array}$ & $\begin{array}{l}30 \text { Dec. } \\
1667\end{array}$ & 10 years & $\begin{array}{l}\text { Karton 23, no. 35, fols. } \\
409^{\mathrm{r}}-411^{\mathrm{v}} \text { (application } \\
\text { in composer's hand, } \\
\text { dated } 20 \text { Dec. } 1667 ; \\
\text { draft privilege) }\end{array}$ & Sonate, op. 7 (c. 1667), RISM A/I Z176 \\
\hline
\end{tabular}




\section{Protected Publications}

honour of a perpetual imperial privilege, complementing the privileges he received from the French king from 1575 onwards. ${ }^{17}$ Other holders of imperial privileges presumably gained these through their connections with the Habsburg court. Hans Leo Hassler, who gained a privilege in 1591, would later be ennobled by Rudolf II and named as an imperial servant; ${ }^{18}$ and Pietro Andrea Ziani, who successfully petitioned for a privilege for his Sonate opus 7, was Kapellmeister for dowager Empress Eleonora from 1662 to 1669 . Imperial privileges also protected music published in free cities that were subordinate only to the emperor, as with the privileges obtained by the Hamburg musician Johann Schop, or by the Hamburg publisher Georg Ludwig Frobenius for the music of Hieronymus Praetorius.

Table 3 shows composers who held Saxon printing privileges, as documented by newly discovered papers in the Sächsisches Hauptstaatsarchiv; Table 4 shows publishers who held Saxon privileges specifically for music. Although music books from the 1570s onwards mention Saxon privileges on their title pages ${ }^{19}$ the first Saxon privileges for musicians to be documented archivally date from 1594. Saxon privileges were mostly held by musicians from that territory, including composers connected to the Dresden court such as Schütz (Kapellmeister $c .1618$ to $c$. 1656), Michael Praetorius (acting Kapellmeister, c. 1613-17) and Caspar Kittel (court organist in the mid1630s). There are also town musicians such as Calvisius (Leipzig Thomaskantor from 1594 to 1615), Schein (Leipzig Thomaskantor from 1616 to 1630), Michael Lohr (cantor at Dresden's Kreuzkirche from 1625 to 1654) and Hammerschmidt (organist in Freiberg and later in Zittau).

Occasionally Saxon privileges were acquired by composers working further afield, for instance in 1622 by Johannes Schultz (organist at the Brunswick-Lüneburg court in Dannenberg), or in 1658 by Lorenz Erhard (cantor in Frankfurt am Main). Such musicians may have wanted to protect their publications at the Leipzig book fair, in the

${ }^{17}$ J. Haar, 'Orlando di Lasso, Composer and Print Entrepreneur', in K. van Orden (ed.), Music and the Cultures of Print (New York, 2000), pp. 125-62, at pp. 135, 140-2.

${ }^{18}$ H. Krones, 'Die Beziehungen der Brüder Haßler zu Kaiser Rudolf dem II. und zu Prag', in K. W. Niemöller and H. Loos (eds.), Die Musik der Deutschen im Osten und ihre Wechselwirkung mit den Nachbarn (Bonn, 1994), pp. 375-81.

19 See, for instance, the music books of Gallus Dressler, including his XC Cantiones quatuor, quinque et plurium vocum (Magdeburg, 1570), RISM A/I D3520, where the title page of the tenor partbook reads 'Cum gratia et privilegio illustrissimi principis ac domini, D. Augusti Ducis Saxoniae Electoris, \& c. ad quinquennium'; and his XVI. Geseng mit vier und mehr Stimmen componiret (Magdeburg, 1570), RISM A/I D3524, with 'Mit Churfürstlicher Sechsischer befreyhung' on the title page of the tenor partbook. 
Table 3 Composers who held Saxon printing privileges 1590-1700, as documented by evidence in Sächsisches Hauptstaatsarchiv

\begin{tabular}{|c|c|c|c|c|}
\hline Composer & $\begin{array}{l}\text { Date of } \\
\text { privilege }\end{array}$ & Duration & $\begin{array}{l}\text { Archival evidence (D-Dla except } \\
\text { where stated) }\end{array}$ & $\begin{array}{l}\text { Extant publications that mention } \\
\text { privilege }\end{array}$ \\
\hline \multirow[t]{2}{*}{$\begin{array}{l}\text { CALVISIUS, Seth (1556- } \\
\text { 1615) }\end{array}$} & 16 Apr. 1594 & 6 years & $\begin{array}{l}\text { Loc. } 7300 / 2, \text { Bd. } 1 \text {, fol. } 511^{\mathrm{r}-\mathrm{v}} \\
\quad \text { (application dated } 26 \text { Mar. 1594); } \\
\text { fol. } 512^{\mathrm{r}-\mathrm{v}} \text { (draft privilege) }\end{array}$ & $\begin{array}{l}\text { Privilege specifies Hymni sacri } \\
\text { (Erfurt, 1594) but it is not } \\
\text { mentioned there; instead it is } \\
\text { mentioned on Harmonia } \\
\text { cantionum ecclesiasticarum } \\
\text { (Leipzig, 1597/2nd edn } 1598 \text { ), } \\
\text { RISM B/VIII } 1597^{04}, 1598^{05}\end{array}$ \\
\hline & 27 Sept. 1611 & 10 years & $\begin{array}{l}\text { Loc. } 10757 / 1 \text {, fol. } 353^{\mathrm{r}-\mathrm{v}} \text { (draft } \\
\text { privilege); fol. } 354^{\mathrm{r}-\mathrm{v}} \text { (application } \\
\text { dated } 12 \text { Sept. } 1611)\end{array}$ & $\begin{array}{l}\text { Harmonia cantionum ecclesiasticarum, } \\
\text { 4th edn (Leipzig, 1612), RISM B/ } \\
\text { VIII } 1612^{03}\end{array}$ \\
\hline $\begin{array}{l}\text { DEMANTIUS, Christoph } \\
\quad(1567-1643)\end{array}$ & 29 Oct. 1619 & 10 years & $\begin{array}{l}\text { Loc. } 10757 / 2, \text { fols. } 158^{\mathrm{r}-\mathrm{v}}, 164^{\mathrm{r}} \\
\quad \text { (draft privilege), fol. } 159^{\mathrm{r}-\mathrm{v}} \\
\quad \text { (application dated } 26 \text { Oct. } 1619 \text { ) }\end{array}$ & $\begin{array}{l}\text { Privilege specifies Isagoge artis } \\
\text { musicae, 7th edn (Freiberg, 1621) } \\
\text { and Threnodiae . . . ausserlesene } \\
\text { trostreiche Begräbnüß Gesänge } \\
\text { (Freiberg, 1620), RISM A/I } \\
\text { D1542, but is not mentioned on } \\
\text { these works }\end{array}$ \\
\hline $\begin{array}{l}\text { ERHARD, Lorenz (1598- } \\
\text { 1669) }\end{array}$ & 17 Sept. 1658 & 10 years & $\begin{array}{l}\text { Loc. } 10758 / 2 \text {, unfoliated (draft } \\
\text { privilege) (application dated } 15 \\
\text { May } 1658 \text { ) }\end{array}$ & $\begin{array}{l}\text { Harmonisches Chor und Figural } \\
\text { Gesang-Buch (Frankfurt am Main, } \\
\text { 1659), RISM A/I E746 }\end{array}$ \\
\hline
\end{tabular}


Table 3 (Continued)

\begin{tabular}{|c|c|c|c|c|}
\hline Composer & $\begin{array}{l}\text { Date of } \\
\text { privilege }\end{array}$ & Duration & $\begin{array}{l}\text { Archival evidence (D-Dla except } \\
\text { where stated) }\end{array}$ & $\begin{array}{l}\text { Extant publications that mention } \\
\text { privilege }\end{array}$ \\
\hline
\end{tabular}

\begin{tabular}{|c|c|c|}
\hline $\begin{array}{l}\text { GROPPENGIESSER, } \\
\text { Johann }\end{array}$ & $\begin{array}{l}12 \text { Aug. } 1611 \\
\text { (application } \\
\text { only) }\end{array}$ & - \\
\hline \multirow[t]{2}{*}{$\begin{array}{l}\text { HAMMERSCHMIDT, } \\
\text { Andreas }(c .1611-75)\end{array}$} & 22 Jan. 1638 & 10 years \\
\hline & 24 Mar. 1662 & 10 years \\
\hline $\begin{array}{l}\text { KITTEL, Caspar (1603- } \\
\text { 39) }\end{array}$ & $\begin{array}{l}\text { 16 July } 1638 \\
\text { (application } \\
\text { only) }\end{array}$ & $?$ \\
\hline $\begin{array}{l}\text { LOHR, Michael (1591- } \\
\text { 1654) }\end{array}$ & 23 Nov. 1636 & 10 years \\
\hline
\end{tabular}

Loc. 100024, fols. $8^{\mathrm{r}}-9^{\mathrm{v}}$ (application No printed works survive only)

Loc. $10757 / 3$, fols. $467^{\mathrm{r}}-468^{\mathrm{r}}$ (draft Mentioned on some issues of privilege with uncut printed copy Musicalischer Andacht Erster Theil of Andere Stimme of Musicalischer (Freiberg, 1638-9), RISM A/I Andacht Erster Theil)

H1922, e.g. GB-Lbl, Dritte Stimme partbook (dated 1638) shelfmark D.35

Loc. 10758/3, fols. $34^{\mathrm{r}-\mathrm{v}}, 37^{\mathrm{r}}$ (draft Kirchen- und Tafel Music (Zittau, privilege for Kirchen- und Tafel Music), fols. $35^{\mathrm{r}}-36^{\mathrm{v}}$ (application dated 6 Mar. 1662)

Loc. $10757 / 3$, fol. $500^{\mathrm{r}}$ (application Arien und Cantaten mit 1. 2. 3. und 4. dated 16 July 1638)

Stimmen (Dresden, 1638), RISM A/I K853

Loc. $10757 / 3$, fols. $416^{\mathrm{r}}-417^{\mathrm{r}}$ (draft Ander Theil. Neuer Teutscher und privilege, with manuscript draft of Lateinischer KirchenGesänge und title page of Ander Theil. Neuer Teutscher . . . KirchenGesänge und Concerten (Dresden, 1637), RISM A/I L2761 
Table 3 (Continued)

\begin{tabular}{|c|c|c|c|c|}
\hline Composer & $\begin{array}{l}\text { Date of } \\
\text { privilege }\end{array}$ & Duration & $\begin{array}{l}\text { Archival evidence (D-Dla except } \\
\text { where stated) }\end{array}$ & $\begin{array}{l}\text { Extant publications that mention } \\
\text { privilege }\end{array}$ \\
\hline $\begin{array}{l}\text { PRAETORIUS, Michael } \\
\quad(c .1571-1621)\end{array}$ & 4 Nov. 1614 & 10 years & $\begin{array}{l}\text { Loc. } 10757 / 1 \text {, fol. } 537^{\mathrm{r}-\mathrm{v}} \text { (draft } \\
\text { privilege for four volumes of } \\
\text { Syntagma musicum); fol. } 538^{\mathrm{r}} \\
\text { ('Bescheidtt, auf ... Michaëlis } \\
\text { Prætorij Supplication', } 31 \text { Oct. } \\
\text { 1614); fol. 539 } 9^{\mathrm{r}-\mathrm{v}} \text { (letter to } \\
\text { Matthias Hoë von Hoënegg } \\
\text { regarding application, } 13 \text { Oct. } \\
\text { 1614) }\end{array}$ & $\begin{array}{l}\text { Not mentioned on any of his } \\
\text { treatises }\end{array}$ \\
\hline RATZ, Abraham & 3 Sept. 1594 & perpetual & $\begin{array}{l}\text { Loc. } 07301 / 01 \text {, fols. } 387^{\mathrm{r}-\mathrm{v}}, 390^{\mathrm{r}} \\
\quad \text { (draft privilege); fols. } 388^{\mathrm{r}}-389^{\mathrm{v}} \\
\quad \text { (petition dated } 24 \text { Aug. } 1594 \text { ) }\end{array}$ & $\begin{array}{l}\text { Threni amorum. Der erste Theil lustiger } \\
\text { welticher Lieder . . von dem } \\
\text { hochberümbten Jacobo Regnarto } \\
\text { (Nuremberg, 1595) / Der ander } \\
\text { Theil lustiger weltlicher Lieder } \\
\text { (Nuremberg, 1595), RISM A/I } \\
\text { R741-2 }\end{array}$ \\
\hline \multirow[t]{2}{*}{$\begin{array}{l}\text { SCHEIN, Johann } \\
\text { Hermann (1586-1630) }\end{array}$} & 4 July 1617 & 10 years & $\begin{array}{l}\text { Loc. } 10757 / 2 \text {, fols. } 59^{\mathrm{r}-\mathrm{v}}, 62^{\mathrm{r}} \text { (draft } \\
\text { privilege), fols. } 60^{\mathrm{r}}-61^{\mathrm{v}} \\
\text { (application dated } 1 \text { July } 1617 \text { ) }\end{array}$ & \multirow{2}{*}{$\begin{array}{l}\text { Opella nova I (Leipzig, 1618, 2nd } \\
\text { edn 1627); Musica boscareccia I, II } \\
\text { and III (Leipzig, 1621, 1626, } \\
\text { 1628); Israelis Brünlein (Leipzig, } \\
\text { 1623); Diletti pastorali (Leipzig, } \\
\text { 1624); Studenten-Schmauß } \\
\text { (Leipzig, 1626); Cantional } \\
\text { (Leipzig, 1627), RISM A/I }\end{array}$} \\
\hline & 17 Nov. 1628 & 10 years & $\begin{array}{l}\text { Loc. } 10757 / 3 \text {, fols. } 76^{\mathrm{r}-\mathrm{v}}, 79^{\mathrm{r}} \text { (draft } \\
\text { privilege); fols. } 77^{\mathrm{r}}-78^{\mathrm{v}} \\
\text { (application dated } 13 \text { Nov. } 1628) \text {. } \\
\text { Fair copy of privilege in D-LEsm, } \\
\text { A/4298/2009 }\end{array}$ & \\
\hline
\end{tabular}


Table 3 (Continued)

\begin{tabular}{|c|c|c|c|c|}
\hline Composer & $\begin{array}{l}\text { Date of } \\
\text { privilege }\end{array}$ & Duration & $\begin{array}{l}\text { Archival evidence (D-Dla except } \\
\text { where stated) }\end{array}$ & $\begin{array}{l}\text { Extant publications that mention } \\
\text { privilege }\end{array}$ \\
\hline \multirow{4}{*}{$\begin{array}{l}\text { SCHÜTZ, Heinrich } \\
\quad(1585-1672)\end{array}$} & & & & $\begin{array}{l}\text { S1377-80, 1385, 1387-90, 1395, } \\
1397,1399-1400\end{array}$ \\
\hline & 17 Apr. 1618 & 8 years & $\begin{array}{l}\text { Loc. } 10757 / 2 \text {, fols. } 84^{\mathrm{r}-\mathrm{v}} \text { and } 89^{\mathrm{r}} \\
\quad \text { (draft privilege); fol. } 85^{\mathrm{r}-\mathrm{v}} \\
\quad \text { (application dated } 15 \text { Apr. 1618) }\end{array}$ & $\begin{array}{l}\text { Privilege covers Psalmen Davids } \\
\text { (Dresden, 1619), RISM A/I } \\
\text { S2275, but is not mentioned on } \\
\text { this book }\end{array}$ \\
\hline & 3 Aug. 1627 & 10 years & $\begin{array}{l}\text { Loc. } 10757 / 2 \text { : fols. } 589^{\mathrm{r}-\mathrm{v}}, 593^{\mathrm{r}} \\
\text { (draft privilege); fols. } 590^{\mathrm{r}}-591^{\mathrm{v}} \\
\text { (application, dated } 2 \text { Aug. } 1627 \text { ); } \\
\text { fol. } 592^{\mathrm{r}} \text { (manuscript draft of title } \\
\text { page) }\end{array}$ & $\begin{array}{l}\text { Psalmen Davids/ hiebevorn in Teutzsche } \\
\text { Reimen gebracht/ Durch D. } \\
\text { Cornelium Beckern [Becker Psalter] } \\
\text { (Freiberg, 1628), RISM A/I } \\
\text { S2282 }\end{array}$ \\
\hline & 10 Aug. 1636 & 10 years & $\begin{array}{l}\text { Loc. } 10757 / 3 \text { : unfoliated leaves } \\
\text { before fol. } 406^{\mathrm{r}} \text { include } \\
\text { application (dated } 9 \text { Aug. 1636), } \\
\text { undated request to reduce the } \\
\text { number of deposit copies, and } \\
\text { draft privilege }\end{array}$ & $\begin{array}{l}\text { Erster Theil Kleiner geistlichen Concerten } \\
\text { (Leipzig, 1636), RISM A/I S2290 }\end{array}$ \\
\hline $\begin{array}{l}\text { SCHULTZ, Johannes } \\
\quad(1582-1653)\end{array}$ & 14 Oct. 1622 & 10 years & $\begin{array}{l}\text { Loc. } 10757 / 2 \text {, fols. } 334^{\mathrm{r}-\mathrm{v}}, 339^{\mathrm{r}} \\
\text { (application dated } 27 \text { Apr. 1622); } \\
\text { fols. } 335^{\mathrm{r}-\mathrm{v}}, 338^{\mathrm{r}} \text { (draft privilege); } \\
\text { fols. } 336^{\mathrm{r}}-337^{\mathrm{v}} \text { (letter of support } \\
\text { dated } 28 \text { Apr. } 1622 \text { from Julius } \\
\text { Ernst of Brunswick-Dannenberg) }\end{array}$ & $\begin{array}{l}\text { Privilege specifies Musicalischer } \\
\text { Lüstgarte (Lüneburg, 1622), RISM } \\
\text { A/I S2329 but is not mentioned } \\
\text { in this book }\end{array}$ \\
\hline
\end{tabular}


Table 3 (Continued)

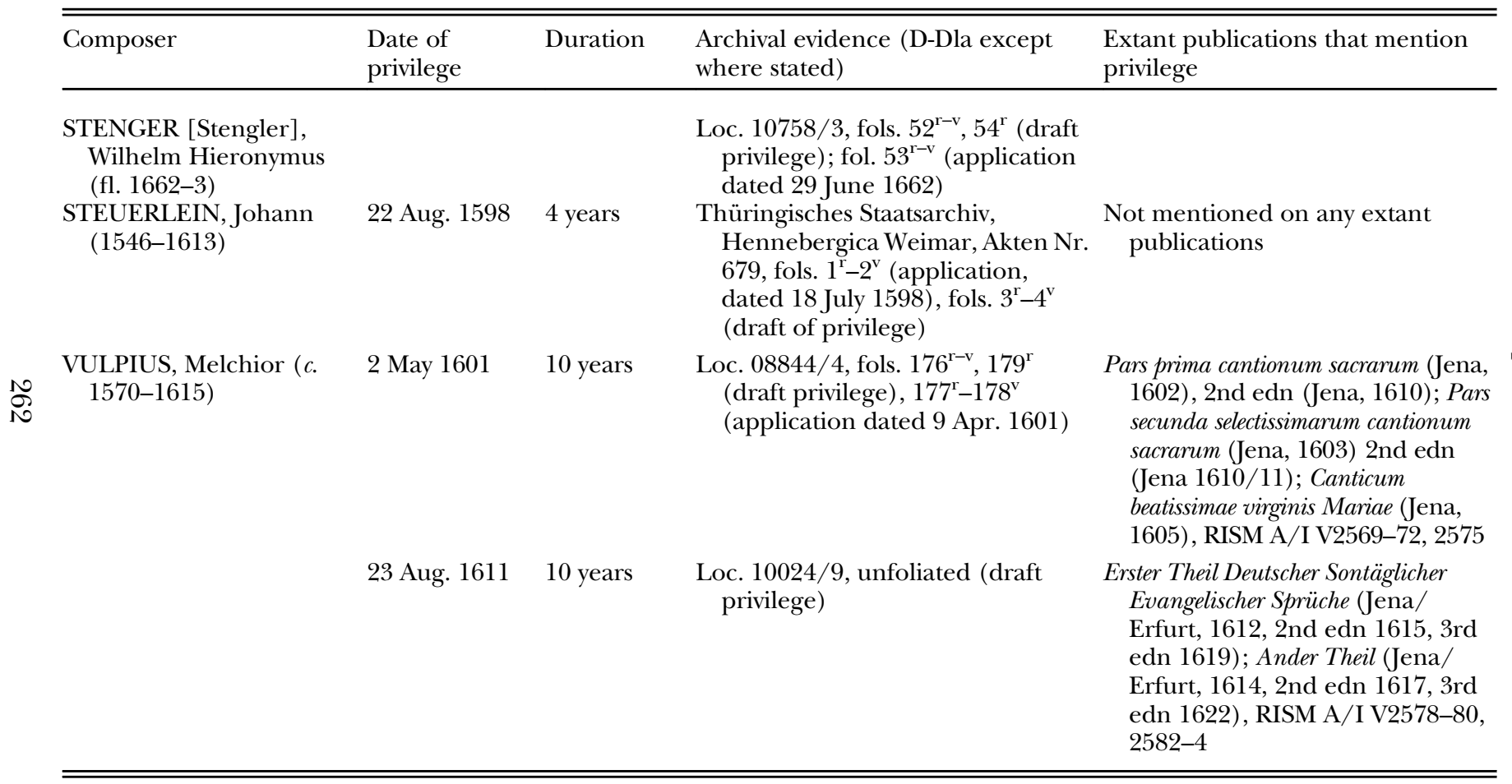


Table 4 Saxon privileges granted to publishers for musical items 1600-1700, as documented by evidence in Sächsisches Hauptstaatsarchiv

Composer $\quad$ Publisher $\quad$ Date of $\quad$ Duration Archival evidence (D-Dla) Works mentioned in privilege

(place) privilege

\begin{tabular}{|c|c|c|c|c|c|}
\hline $\begin{array}{l}\text { BODENSCHATZ, } \\
\text { Erhard } \\
\quad(c .1576-1636)\end{array}$ & $\begin{array}{l}\text { Abraham } \\
\text { Lamberg } \\
\text { (Leipzig) }\end{array}$ & renewed 1611 & unspecified & Loc. $10757 / 1$, fol. $313^{v}$ & $\begin{array}{l}\text { Florilegium selectissimarum } \\
\text { cantionum (1603), RISM B/I } \\
\text { 1603 }^{1} \text {; Psalterium Davidis } \\
(1607), \text { RISM A/I B3241; } \\
\text { Harmoniae angelicae cantionum } \\
\text { ecclesiasticarum (1608), RISM } \\
\text { A/I B3242 }\end{array}$ \\
\hline $\begin{array}{l}\text { CALVISIUS, Seth } \\
(1556-1615)\end{array}$ & $\begin{array}{l}\text { Bartholomäus } \\
\text { Voigt } \\
\text { (Leipzig) }\end{array}$ & 1 Mar. 1632 & 15 years & $\begin{array}{l}\text { Loc. } 10757 / 3 \text {, fols. } 215^{\mathrm{r}-\mathrm{v}} \text {, } \\
226^{\mathrm{r}} \text { (draft privilege), } \\
216^{\mathrm{r}}-223^{\mathrm{v}} \text { (application } \\
\text { dated } 22 \text { Feb. 1632) }\end{array}$ & $\begin{array}{l}\text { Harmonia cantionum } \\
\text { ecclesiasticarum. No edition } \\
\text { from this date is known. }\end{array}$ \\
\hline $\begin{array}{l}\text { CRÜGER, Johannes } \\
\quad(1598-1662)\end{array}$ & $\begin{array}{l}\text { Balthasar Mevius } \\
\text { (Wittenberg) }\end{array}$ & 20 Feb. 1657 & 10 years & $\begin{array}{l}\text { Loc. } 10758 / 2 \text {, unfoliated } \\
\text { (draft privilege and } \\
\text { application) }\end{array}$ & $\begin{array}{l}\text { Praxis pietatis melica (Frankfurt / } \\
\text { Wittenberg, 1656), RISM B/ } \\
\text { VIII } 1656^{06}\end{array}$ \\
\hline
\end{tabular}

\begin{tabular}{|c|c|c|c|c|}
\hline $\begin{array}{l}\text { Balthasar } \\
\text { Christoph } \\
\text { Wust } \\
\text { (Frankfurt }\end{array}$ & 26 Mar. 1675 & 10 years & $\begin{array}{l}\text { Loc. } 10758 / 4 \text {, unfoliated } \\
\quad \text { (draft privilege; } \\
\text { application dated } 12 \\
\text { Mar. 1675) }\end{array}$ & $\begin{array}{l}\text { Praxis pietatis melica (Frankfurt } \\
\text { am Main, 1674), RISM B/VIII } \\
1674^{07}\end{array}$ \\
\hline
\end{tabular}

Loc. $10758 / 3$ fols. $200^{\mathrm{r}}-201^{\mathrm{v}}$ (application dated 1 June 1665)

am Main) application dated 12 
Table 4 (Continued)

\begin{tabular}{lllll}
\hline \hline Composer & $\begin{array}{l}\text { Publisher } \\
\text { (place) }\end{array}$ & $\begin{array}{l}\text { Date of } \\
\text { privilege }\end{array}$ & Duration & Archival evidence (D-Dla) Works mentioned in privilege \\
\hline
\end{tabular}

HAMMERSCHMIDT, Christian and

Andreas

(c. 1611-75)

Melchior

Bergen

(Dresden)

HINTZE, Jacob

(1622-1702)

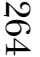

\footnotetext{
HORN, Johann

Caspar (1636-

1722)
}
Georg Heinrich Frommen
(Dresden)
12 Sept. 167310 years
Johann
Christoph
Mieth

(Dresden)

Völcker, Rupert (Berlin)

21 May $1661 \quad 10$ years

10 years

27 June 167910 years

(n)

14 Apr. 1656 unspecified Loc. 10758/2, unfoliated (draft privilege)

Loc. $10758 / 3$, fols. $9^{\mathrm{r}-\mathrm{v}}, 12^{\mathrm{r}}$
(draft privilege); fols.
$10^{\mathrm{r}}-11^{\mathrm{v}}$ (undated application)
Loc. 10758/4, unfoliated (draft privilege;

applications dated 27 Aug. and 8 Sept. 1673)

Loc. 10759/1, unfoliated (draft privilege; printed sample of Geistliche

Harmonien . . Winter Theil title page)

Musicalische Gespräche über die Evangelia (Dresden, 1655); Ander Theil Geistlicher Gespräche über die Evangelia (Dresden, 1656), RISM A/I 1948-9

Martin Opitzens in deutsche Reimen verfasste Episteln . . . anitzo Mit besonderen Melodeyen, dieses mal aber nur der Choral nebenst dem Basso Continuo (Frankfurt an der Oder, 1661), RISM B/VIII $1661^{10}$

Schertzende Musen-Lust (Leipzig, 1673-4), RISM A/I H7416

\section{Geistliche Harmonien über die} gewöhnlichen Evangelia . . Winter Theil (Dresden, 1680), Sommer Theil (Dresden, 16801), RISM A/I H7418-9 
Table 4 (Continued)

\begin{tabular}{|c|c|c|c|c|c|}
\hline Composer & $\begin{array}{l}\text { Publisher } \\
\text { (place) }\end{array}$ & $\begin{array}{l}\text { Date of } \\
\text { privilege }\end{array}$ & Duration & Archival evidence (D-Dla) & Works mentioned in privilege \\
\hline \multirow[t]{3}{*}{$\begin{array}{l}\text { KRIEGER, Adam } \\
\quad(1634-66)\end{array}$} & $\begin{array}{l}\text { Martin Maier } \\
\text { (Leipzig) }\end{array}$ & 23 Nov. 1656 & 10 years & $\begin{array}{l}\text { Loc. } 10758 / 2 \text {, unfoliated } \\
\quad \text { (draft privilege; } \\
\text { application dated } 9 \text { Nov. } \\
\text { 1656) }\end{array}$ & $\begin{array}{l}\text { Arien (Leipzig, 1657), RISM A/I } \\
\quad \text { K2436 }\end{array}$ \\
\hline & $\begin{array}{l}\text { Anna Krieger } \\
\text { (composer's } \\
\text { mother) }\end{array}$ & 22 Apr. 1667 & 10 years & $\begin{array}{l}\text { Loc. } 10758 / 4 \text {, unfoliated } \\
\quad \text { (draft privilege) }\end{array}$ & $\begin{array}{l}\text { For son's ‘hinterlaßene } \\
\text { Musicalische Sachen', probably } \\
\text { Krieger's Neuer Arien (Dresden, } \\
\text { 1667), RISM A/I K2437 }\end{array}$ \\
\hline & $\begin{array}{l}\text { Martin Gabriel } \\
\text { Hübner } \\
\text { (Dresden) }\end{array}$ & 17 June 1678 & 10 years & $\begin{array}{l}\text { Loc. } 10759 / 1 \text {, unfoliated } \\
\quad \text { (draft privilege; } \\
\text { application dated } 14 \\
\text { June 1678) }\end{array}$ & $\begin{array}{l}\text { 'Musicalia in fol.', probably } \\
\text { Krieger's Neue Arien (Dresden, } \\
\text { 1676), RISM A/I K2438 }\end{array}$ \\
\hline $\begin{array}{l}\text { QUIRSFELD, Johann } \\
\text { (1642-86) }\end{array}$ & $\begin{array}{l}\text { Christoph } \\
\text { Klinger } \\
\text { (Leipzig) }\end{array}$ & 6 Aug. 1679 & 10 years & $\begin{array}{l}\text { Loc. } 10759 / 1 \text {, unfoliated } \\
\text { (draft privilege; } \\
\text { statement by Quirsfeld, } \\
\text { dated } 26 \text { Apr. 1679) }\end{array}$ & $\begin{array}{l}\text { Geistlicher Harffen-Klang (Leipzig, } \\
\text { 1679), RISM B/VIII } 1679^{99}\end{array}$ \\
\hline $\begin{array}{l}\text { SCHEIN, Johann } \\
\text { Hermann } \\
(1586-1630)\end{array}$ & $\begin{array}{l}\text { Jakob Schuster } \\
\quad \text { (Leipzig) }\end{array}$ & 22 Feb. 1641 & 8 years & $\begin{array}{l}\text { Loc. } 10758 / 1 \text {, fols. } 43^{\mathrm{r}-\mathrm{v}} \\
46^{\mathrm{r}} \text { (draft privilege); } \\
\text { fols. } 44^{\mathrm{r}}-45^{\mathrm{v}} \\
\text { (application dated } 14 \\
\text { Feb. 1641) }\end{array}$ & $\begin{array}{l}\text { Opella nova I and II; Cantional; } \\
\text { Diletti pastorali; Studenten- } \\
\text { Schmauß; Musica boscareccia I, II } \\
\text { and III; Israelis Brünlein (see } \\
\text { Table 5) }\end{array}$ \\
\hline
\end{tabular}


Table 4 (Continued)

\begin{tabular}{|c|c|c|c|c|c|}
\hline Composer & $\begin{array}{l}\text { Publisher } \\
\text { (place) }\end{array}$ & $\begin{array}{l}\text { Date of } \\
\text { privilege }\end{array}$ & Duration & Archival evidence (D-Dla) & Works mentioned in privilege \\
\hline & & 31 Jan. 1649 & 8 years & $\begin{array}{l}\text { Loc. } 10758 / 1 \text {, fols. } 233^{\mathrm{r}-\mathrm{v}} \\
\text { (draft privilege); } \\
\text { unfoliated pages following } \\
\text { fol. } 236^{\mathrm{v}} \text { (application } \\
\text { dated } 23 \text { Jan. 1649) }\end{array}$ & \\
\hline
\end{tabular}

S 


\section{Protected Publications}

same way that publishers outside Saxony sometimes acquired Saxon privileges. Alternatively, these musicians may have sought their privileges as a way to gain patronage from the Elector of Saxony: shortly after Schultz applied for a privilege, he dedicated his Musicalischer Lüstgarte to the Elector; ${ }^{20}$ and Erhard's privilege protected a hymnal that set the chorale tunes as used in Saxony. ${ }^{21}$

Otherwise, the tendency for Saxon privileges to be held by local composers and publishers confirms the hypothesis that the German music trade in this period mainly served regional markets. ${ }^{22}$ None of the musicians with Saxon privileges also held imperial privileges, apart from Schütz, who in 1637 gained a five-year imperial privilege (renewed in 1642 for a further ten years). Schütz's shift to imperial privileges may indicate his growing international fame and his desire to promote his music beyond Saxon lands; or it may have been motivated by his efforts to prevent unauthorised reprints (as discussed below).

The musical genres protected by privileges reflect the general trends in the music trade, but also indicate those genres deemed to have particular commercial or symbolic value. From the 1590 s to $1640 \mathrm{~s}$ privileges mainly covered sacred polyphony, the genre that dominated the music trade in those decades and that held substantial prestige for composers. After the 1640s, as the printing of polyphonic music started to decline, privileges were rarely held by composers. Instead they were mainly sought by publishers to protect hymnals (such as Johannes Crüger's Praxis pietatis melica) and songbooks (such as Adam Krieger's Arien) (see Table 4 above). Both genres appealed to the domestic market and were likely to be reprinted; secular songbooks, although often surviving in few copies nowadays, appeared regularly in inventories of personal libraries and may have been purchased for their poetry as much as their music. ${ }^{23}$ As the final section of this article shows, songbooks by Schein and Albert were sufficiently popular to appear in unauthorised editions.

The privileges for instrumental music indicate the changing value attributed to these genres. In the second half of the sixteenth century,

${ }^{20} \mathrm{~J}$. Schultz, Musicalischer Lüstgarte (Lüneburg, 1622), RISM A/I S2329.

${ }^{21}$ L. Erhard, Harmonisches Chor und Figural Gesang-Buch (Frankfurt am Main, 1659), RISM A/I E746.

${ }^{22}$ On the importance of local markets, see E. Giselbrecht, 'Crossing Boundaries: The Printed Dissemination of Italian Sacred Music in German-Speaking Areas (1580-1620)' (Ph.D. diss., University of Cambridge, 2012), pp. 68-9, 226, 241.

${ }^{23}$ For examples of songbooks in personal libraries, see W. Braun, 'Die Musik in deutschen Gelehrtenbibliotheken des 17. und 18. Jahrhunderts', Die Musikforschung, 10 (1957), pp. 241-50, at pp. 242, 248-9. 


\section{Stephen Rose}

several lutenists held imperial privileges for their tablatures, including Melchior Neusidler and Valentin Bakfark (Table 1 above). The Leipzig organist Elias Nikolaus Ammerbach advertised a six-year imperial privilege on the title page of his 1575 keyboard tablature, although no archival evidence exists for it. ${ }^{24}$ Such privileges suggest that composers of instrumental music had a high regard for their printed tablatures, which were regularly reprinted and also boosted their professional status. From the seventeenth century, however, no extant books of printed keyboard music or lute music mention a privilege on their title pages (to the best of my knowledge), although in 1662 the Halle organist Wilhelm Hieronymus Stenger gained a Saxon privilege for 'musicalische werklein durch . . . Kupfferstich' (engraved pieces presumably for keyboard, of which no trace survives). ${ }^{25}$ Ensemble instrumental music was almost never covered by privileges, apart from a few publications by musicians associated with the imperial court such as Ziani's Sonate (c. 1667) and Johann Heinrich Schmelzer's Sonatae unarum fidium, seu a violino solo (1664) (which lists a ten-year imperial privilege on its title page).

Overall, it must be emphasised that archival records do not survive for all the privileges granted for music. Nonetheless the documents summarised in Tables 1 to 4 show how the organisation and regulation of the music trade operated on regional lines, with imperial privileges mainly used by composers connected to the Habsburg family, and with Saxon composers focusing on a local market. The archival records also indicate the musical genres deemed to have particular commercial or symbolic value, and document a number of planned publications that apparently never saw the light of day.

\section{TYPES AND TERMS OF PRIVILEGES}

Whether issued by the Holy Roman Emperor or the Elector of Saxony, privileges had a formulaic structure and set of provisions, into which various details about the specific book were inserted. Privileges usually belonged to one of two types: special or general. Most frequently issued was the privilegium speciale for one or more designated books, as

${ }^{24}$ E. N. Ammerbach, Ein new kunstlich Tabulaturbuch (Nuremberg, 1575), RISM B/I 1575 ${ }^{17}$; it is also mentioned on his Orgel oder Instrument Tabulaturbuch (Nuremberg, 1583), RISM $\mathrm{B} / \mathrm{I} 1583^{22}$.

${ }^{25}$ D-Dla, Loc. $10758 / 3$, fol. $53^{\mathrm{r}}$. Stenger applied unsuccessfully in 1663 for the post of organist at the Ulrichskirche in Halle; see W. Serauky, Musikgeschichte der Stadt Halle. II/i: Von Samuel Scheidt bis in die Zeit Georg Friedrich Händels und Johann Sebastian Bachs (Halle, 1939), p. 321. 


\section{Protected Publications}

listed in the application and in the privilege itself. ${ }^{26}$ The privilege may specify the title of the publication or may give a more general description that nonetheless can be identified as an extant book.

Less often granted were general privileges, which for their duration protected all past, present and future works by a named author or publisher. Such privileges were a sign of a ruler's special favour. Indeed, in 1594 a Saxon ordinance specified that general privileges should not be used, because bookdealers had 'printed many unnecessary and unfit books' under their aegis. ${ }^{27}$ In 1616 general privileges were again rescinded in Saxony, possibly because the Elector sought to maximise the income he received from applications for special privileges. ${ }^{28}$ Some musicians consequently had their applications for general privileges rejected. In 1601 the Weimar cantor Melchior Vulpius requested Saxon protection 'for my current and future compositions', ${ }^{29}$ but received a privilege only for a specific work ('motets for six, seven, eight and more voices, from the Psalms of David and the usual Sunday Gospel readings', probably a reference to his Pars prima cantionum sacrarum). ${ }^{30}$ Ten years later, Vulpius again applied for a Privilegium generale and this time received one, covering 'the current songs setting Gospel sayings for Sundays and all future compositions, even those not based on biblical texts'. ${ }^{31}$ In 1617 Schein apparently had no difficulty obtaining a privilege for his current and future musical works, perhaps because he published these himself. But the Elector's reluctance to grant general privileges was still evident in 1636, when Schütz requested 'a general privilege for all those musical works, which I intend to prepare for publication with the help of God'. ${ }^{32}$ Regardless of his status as court Kapellmeister, Schütz's request was initially refused, with the draft privilege being solely for 'the first and second part of his concertos' (a reference to the Kleine geistliche Concerte). ${ }^{33}$ Subsequently, however, another scribe added a

${ }^{26}$ Lehne, 'Zur Rechtsgeschichte der kaiserlichen Privilegien', p. 341.

${ }^{27}$ L. Gieseke, 'Die kursächsische Ordnung für Buchhändler und Buchdrucker von 1594', Archiv für Geschichte des Buchwesens, 60 (2006), pp. 176-83, at p. 183.

${ }^{28}$ A. Kirchhoff, 'Lesefrüchte aus den Acten des städtischen Archivs zu Leipzig', Archiv für Geschichte des deutschen Buchhandels, 15 (1892), pp. 188-297, at p. 262.

29 'vber itzige vnd künfftige meine compositionen'. D-Dla, Loc. 08844/4, fol. 177v .

30 'etzliche muteten zu 6. 7. 8. vnd mehr stimmen/ aus den Psalmis Davidicis vnd den gewohnlichen SontagsEvangelien'. Ibid., fol. $176^{\mathrm{r}}$.

31 'izterwehnte gesänge aus den Sonntags-Evangelischen sprüchen vnd alle künfftige seine compositiones darinnen doch nichts als biblici textus sein sollen'. D-Dla, Loc. 10024/9.

32 'ein allgemeines privilegium über alle diejenigen musicalische wercke, welche ich mit der hülffe Gottes zur publication verfertigen möchte'. D-Dla, Loc. 10757/3, unfoliated (before fol. $406^{\mathrm{r}}$ ).

33 'vber den ersten vnd andern theil seiner concerten'. Ibid. 


\section{Stephen Rose}

more inclusive reference to 'his musical works' ('seine opera musicalia'). Such negotiations exposed the limits of the favours that princes were prepared to grant in a privilege.

Despite the efforts of rulers to differentiate between special and general privileges, some authors interpreted these documents elastically. Calvisius's 1594 privilege specified 'the Latin hymns and all the German songs which are used in the churches and elsewhere'. 34 This apparently referred to his Hymni sacri latini et germanici (Erfurt, 1594), yet that book does not specify a privilege on its title page. Instead the editions of Calvisius's Harmonia cantionum ecclesiasticarum from 1597 onwards mention his Saxon privilege on their title pages, although this hymnal includes few of the Latin hymns stipulated in the privilege. Indeed in his 1611 application to renew his privilege (see Appendix 1), Calvisius claimed that his initial privilege was for the first edition of his Harmonia cantionum ecclesiasticarum. Either he regarded the Hymni sacri as interchangeable with the Harmonia cantionum, ${ }^{35}$ or he used the bibliographical imprecision of the privilege as a way to extend its protection to another book.

Privileges were usually granted for ten years, although in some cases for shorter or longer periods (see Tables 1 to 4 above). The limited duration of privileges signalled that these were not inherent rights; indeed a Saxon edict of 1625 declared that the Elector could revoke a privilege at any time. ${ }^{36}$ Privileges in perpetuity were rare, granted only to a few celebrated or well-connected individuals. Lassus is the sole musician known to have held a perpetual imperial privilege, an honour exceeding the ten-year duration of his French privilege. In 1594 the Naumburg musician Abraham Ratz gained a perpetual Saxon privilege for various musical projects including German contrafacta of Jacob Regnart's Italian part-songs. ${ }^{37}$ In 1628 Schein sought a perpetual privilege, asking the Elector of Saxony not merely for a ten-year renewal of his previous privilege, but 'because my business for the

34 'die lateinischen hymnos, item alle deutsche gesenge, so in der kirchen und sonst breuchlich'. D-Dla, Loc. 7300/2, Bd. 1, fol. 512; privilege transcribed in Pohlmann, Die Frühgeschichte, p. 277.

35 On Calvisius's Hymni sacri latini et germanici (RISM A/I C257) as the 'little sister' of the Harmonia cantionum ecclesiasticarum, see F. F. Kaern-Biederstedt, Die Harmonia cantionum ecclesiasticarum des Leipziger Thomaskantors Sethus Calvisius: Entstehung, Quellen, Stilistik, Quellenkataloge zur Musikgeschichte, 63a (Wilhelmshaven, 2015), pp. 29-30.

36 Edict reprinted in Codex Augusteus, oder neuvermehrtes Corpus Juris Saxonici, 2 vols. (Leipzig, 1724), i, cols. 411-12.

37 D-Dla, Loc. $0730 / 01$, fol. $387^{\mathrm{v}}$; see Ratz's description of the privilege as perpetual in the dedication of Threni amorum: Der erste Theil lustiger weltlicher Lieder mit fünff Stimmen von dem hochberümbten Jacobo Regnarto (Nuremberg, 1595), sig. A2v (RISM A/I R741). 


\section{Protected Publications}

above-named reasons is so poor and slight [to] confirm and extend it infinitely after my death for the benefit of my poor wife and children' (see Appendix 4). This request - hinting at Schein's awareness of his mortality, perhaps from his long-standing problems with tuberculosis, gout and kidney stones ${ }^{38}$ - was not granted by the Elector. As discussed below, princes gained power and income from granting privileges, and it was therefore in their financial interest to maintain a steady flow of applications.

Another set of standard stipulations concerned the penalties for those who printed or sold unauthorised copies. In imperial and Saxon privileges alike, such infringers were threatened with confiscation of their stock and with a fine (paid half to the ruler, half to the holder of the privilege). The fines were for substantial amounts. Saxon privileges normally specified a fine of one hundred gold (or Rhenish) florins, ${ }^{39}$ a sum roughly equivalent to the retail cost of about one hundred sets of partbooks. ${ }^{40}$ Imperial privileges specified a fine in fullweight unalloyed (Löthiges) gold; the standard penalty was 10 marks, ${ }^{41}$ as stipulated in Johann Schop's privilege of 1640, but lower penalties were stated in other musicians' privileges (5 marks in Schütz's 1637 privilege; 4 marks in Albert's 1648 privilege).

Uniquely, imperial privileges permitted holders to take the law into their own hands and confiscate unauthorised copies themselves. Albert's privilege gave him the right 'with the help and action of each place's authority, wherever [the pirated copies] are to be found, to confiscate them by his own force, without impediment . . . whereby he shall have committed no crime'. ${ }^{42}$ Such a provision reflected the Emperor's status as a supreme power over German territories, but also the difficulties in upholding his edicts in the absence of a coherent apparatus of state. A similar clause is found in Schütz's 1637 and 1642 imperial privileges. By recognising these formulaic elements in privileges, it is possible to identify the aspects unique to a particular author

38 Mentioned in the funeral oration for Schein, quoted in A. Prüfer, Johan Herman Schein (Leipzig, 1895), p. 137.

39 See Vulpius's 1601 privilege and Schein's 1617 privilege (details in Table 3).

${ }^{40}$ A 1654 inventory from Pirna gives prices for unbound copies of partbook editions such as Schein's Israelis Brünlein (1 thaler, equivalent to 1 florin 3 groschen), Tobias Michael's Musicalischer Seelenlust Erster Theil (1 thaler) and Michael's Musicalischer Seelenlust Ander Theil (21 groschen, equivalent to 1 florin). W. Nagel, 'Die Kantoreigesellschaft in Pirna', Monatshefte für Musikgeschichte, 28 (1896), pp. 148-66, at pp. 158-9.

${ }^{41}$ Lehne, 'Zur Rechtsgeschichte der kaiserlichen Privilegien', p. 388.

42 'welchen vielbenanter Alberti, mit hülf und zuthun eines jeden orts obrigkeit, wo sie dergleichen bei eür iedem finden würden, aus aigenem [sic] gwalt, ohne eintrag menniglichs zu sich nemmen'. A-Wsta, Impressoria, Karton 1, no. 7, fol. $26^{r}$. 


\section{Stephen Rose}

or book, and thereby to use these legal documents to illuminate the publishing arrangements for specific editions.

\section{APPLYING FOR A PRIVILEGE}

As its name suggests, a privilege was not an individual right but a temporary suspension of common law, a sign of special favour by a prince to an individual. Consequently the procedure for obtaining a privilege was highly ritualised, involving the symbolic submission of the applicant to the authority of the prince. In return for the granting of a privilege, the prince typically demanded payment of a fee, the right to censor the books, and a supply of deposit copies.

In the Holy Roman Empire, privilege applications were handled by the imperial chancery (Reichskanzlei); this was the main administrative organ of imperial government and was staffed by lawyers, humanists and career civil servants. ${ }^{43}$ Decisions on privileges may have been taken by the vice-chancellor or the chancery secretary, whose signatures appear on the privilege documents. ${ }^{44}$ In Saxony, applications were managed by the upper consistory (Oberkonsistorium), which was responsible for church discipline and for regulating the book trade via its subsidiary, the Leipzig book commission. It was staffed by clergy (including the senior court chaplain and the superintendent of Dresden's churches) and jurists who acted as electoral court councillors. The Elector was probably not involved in decisions on applications (although a scribbled note filed with Michael Praetorius's draft privilege indicates it was 'most graciously granted' by the Elector himself) ${ }^{45}$ the Elector's signature, as found on some privileges (see Figure 1 below), has not yet been verified as autograph.

As the first step in obtaining a privilege, an individual submitted a petition, normally addressed to the Emperor or Elector as appropriate. The justifications given in these petitions are considered in the section below. In Saxony some applicants evidently presented their submissions in person to the upper consistory: typically their petitions were dated the day before the privilege was drafted, which would have been insufficient time for a letter to travel in the post and be processed by the court administrators. Indeed, Schein's 1617 application was

\footnotetext{
${ }^{43}$ L. Gross, Die Geschichte der deutschen Reichshofkanzlei von 1559 bis 1806 (Vienna, 1933).

${ }^{44}$ Schütz's 1637 imperial privilege, for instance, is signed by the chancery secretary Johann Söldner (A-Wsta, Impressoria, Karton 61, Konvolut 1, no. 3, fol. $6^{\mathrm{r}}$ ). See also Maclean, Scholarship, Commerce, Religion, pp. 144, 148.

45 D-Dla, Loc. $10757 / 1$, fol. $538^{\mathrm{r}}$.
} 


\section{Protected Publications}

signed by the composer in Dresden rather than his current place of residence, Leipzig (Appendix 3). Some applicants also lobbied members of the chancery or upper consistory for favourable treatment of their petitions. In 1614 Michael Praetorius wrote to the Dresden chief court chaplain Matthias Hoë von Hoënegg, the assessor on the upper consistory (Appendix 2): the letter states his request for a privilege for the four volumes he planned of Syntagma musicum, ${ }^{46}$ and mentions that the consistory would shortly receive his other letters (presumably including a petition addressed to the Elector that does not survive).

Petitions for a privilege were often accompanied by additional material such as a letter of endorsement from a patron or sample pages from the proposed book. Lassus's 1581 application for an imperial privilege was accompanied by a letter from Wilhelm $\mathrm{V}$ of Bavaria, testifying that his Kapellmeister's request was 'not unnecessary', and stating that the privilege would benefit and honour not just Lassus and the House of Bavaria, but also the Emperor and the whole of Christendom. ${ }^{47}$ Similarly, Johannes Schultz supplemented his 1622 petition for a Saxon privilege with a letter of recommendation from his patron Julius Ernst of Brunswick-Dannenberg. ${ }^{48}$ Sample material might include handwritten mock-ups of the title page (as in Schütz's 1627 application for his Becker Psalter, or Lohr's 1636 application for his Ander Theil . . . KirchenGesänge) or extracts from the printed proofs (the 1679 application for Johann Caspar Horn's Geistliche Harmonien included a printed copy of the title page of the Winter Theil of that collection). ${ }^{49}$ Such sample material was not necessarily scrutinised closely. The draft of Hammerschmidt's 1638 Saxon privilege survives with an unbound partbook of his Musicalischer Andacht Erster Theil for which the pages are uncut, and thus the members of the upper consistory could not have read more than the title page. ${ }^{50}$

If the chancery or upper consistory reached a favourable decision, a draft privilege was prepared by a secretary; this is the document that

\footnotetext{
${ }^{46}$ The fourth volume of Syntagma musicum never appeared, but according to the plan stated in Praetorius's first volume of Syntagma musicum (Wittenberg, 1615, sig. B5 ${ }^{\mathrm{r}}$ ) it would have been a treatise on composition.

${ }^{47}$ Lassus's and Wilhelm V's letters are transcribed in H. Vanhulst, 'Lasso et ses éditeurs: Remarques à propos de deux lettres peu connues', Revue Belge de Musicologie, 39-40 (19856), pp. 80-100, at pp. 94-6; see also H. Leuchtmann, 'Ein neugefundener Lasso-Brief', in E. Herttrich and H. Schneider (eds.), Festschrift Rudolf Elvers zum 60. Geburtstag (Tutzing, 1985), pp. 349-57.

${ }^{48}$ D-Dla, Loc. $10757 / 2$, fols. $336^{\mathrm{r}}-337^{\mathrm{v}}$.

${ }^{49}$ D-Dla, Loc. $10757 / 2$, fol. $592^{\mathrm{r}}$; Loc. 10757/3, before fol. $417^{\mathrm{r}}$; Loc. 10759/1, unfoliated.

${ }^{50}$ D-Dla, Loc. 10757/3, unpaginated insertion between fols. $467^{\mathrm{v}}$ and $468^{\mathrm{r}}$.
} 


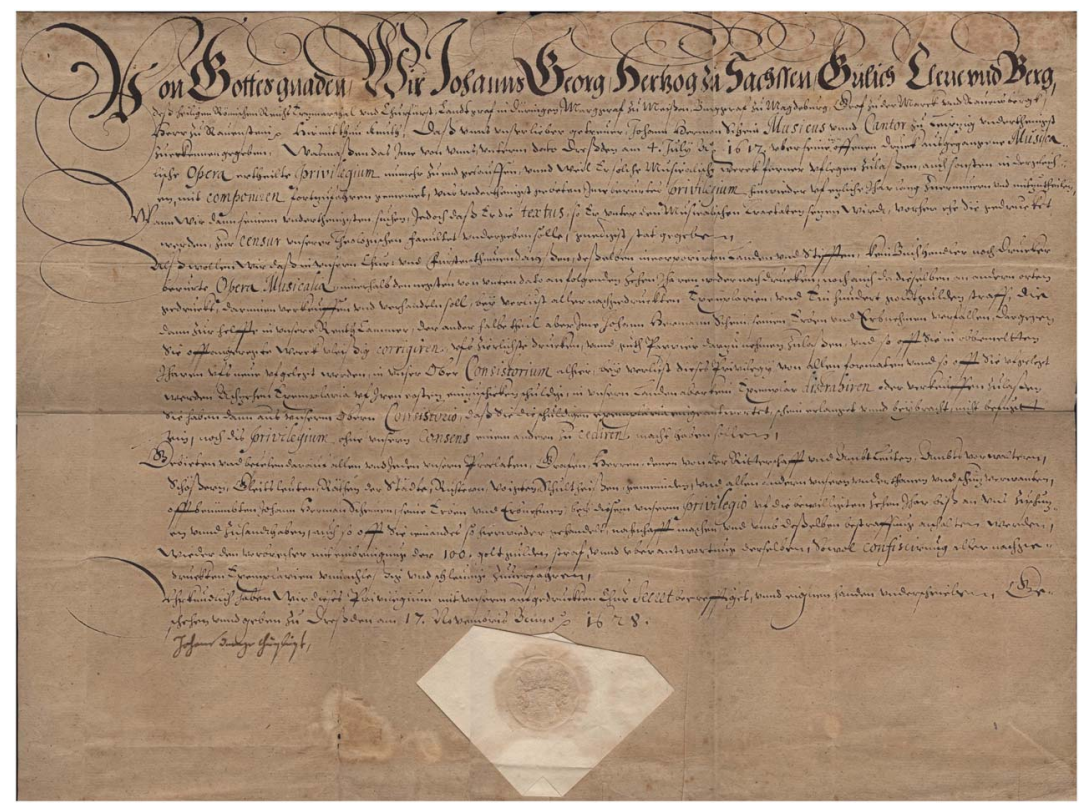

Figure 1 Fair copy of Saxon privilege issued to Johann Hermann Schein, 17 November 1628. Leipzig, Stadtgeschichtliches Museum, A/4298/2009.

Reproduced by permission

usually survives in the imperial or Saxon archives, often with evidence of redrafting (sometimes in more than one hand). In some cases the imperial archives contain merely the letter of application with an official annotation indicating that the privilege was granted. In Saxony a fair copy of the privilege was made on a bifolium and sent to the applicant. Figure 1 shows the fair copy of Schein's 1628 printing privilege, with the signature and seal of Johann Georg I of Saxony. ${ }^{51}$ The grandeur of these Saxon documents asserted the Elector's authority, perhaps with the aim of convincing lesser officials to uphold the privilege.

Several aspects of the application procedure emphasised the power of the prince and assisted those rulers who used the privilege system to control the book trade. First, at least some applicants had to pay a fee for a privilege. In the 1520s, the correspondence between Erasmus and Willibald Pirckheimer shows that a payment of 'twenty gold pieces' was

${ }^{51}$ D-LEsm, Sammlung Autographen, A/4298/2009. 


\section{Protected Publications}

usually necessary to secure a general imperial privilege, but the fee could be avoided by petitioning sympathetic officials. ${ }^{52}$ With regard to Saxon privileges, Jürgen Gramlich has stated there is no evidence of fees being charged; ${ }^{53}$ yet the documents uncovered for this article suggest otherwise. Michael Praetorius's 1614 letter to the Saxon chief court chaplain refers to the payment of a 'chancery fee', a task he had delegated to the Dresden court instrumentalist Michael Mölich (Appendix 2). At the time, Praetorius was working as guest Kapellmeister at the Saxon court (although the privilege document uses his official title of Kapellmeister at the Brunswick court), so it is slightly surprising that he expected to pay a fee. Other applicants for Saxon privileges stressed their loyal service to the Wettin dynasty, perhaps in an attempt to avoid a fee. Schein's 1617 and 1628 petitions referred to his four years as a chorister at the electoral court chapel and his short spell as Kapellmeister for the Ernestine branch of the family in Weimar (Appendices 3 and 4). Yet Praetorius's letter raises the possibility that even musicians with official Saxon appointments, such as Caspar Kittel and Heinrich Schütz, paid a fee to obtain their privileges.

Princely authority was further enhanced by the attempts at censorship that often accompanied the granting of a privilege. Most territories had a system of censorship by church or university authorities, whereby books were approved prior to publication. ${ }^{54}$ Applicants for imperial privileges sometimes submitted certificates to show their books had been approved by the censor in their local jurisdiction, and from the late $1570 \mathrm{~s}$ imperial privileges often included a proviso that the books contain nothing damaging to the Catholic faith. ${ }^{55}$ Imperial privileges drafted in Latin occasionally show attempts by the chancery to censor the texts of vocal music. The 1588 imperial privilege to Jacobus Handl for his 'church songs' (canti ecclesiastici) specified that the texts and preface should contain nothing scandalous or contrary

${ }^{52}$ Letter of Willibald Pirckheimer to Erasmus, 28 Jan. 1523; The Collected Works of Erasmus, ix: The Correspondence of Erasmus. Letters 1252 to 1355 (1522 to 1523), trans. R. A. B. Mynors, annotated by J. M. Estes (Toronto, 1989), letter no. 1344, pp. 407-8.

53 J. Gramlich, 'Rechtsordnungen des Buchgewerbes im Alten Reich: Genossenschaftliche Strukturen, Arbeits- und Wettbewerbsrecht im deutschen Druckhandwerk', Archiv für Geschichte des Buchwesens, 41 (1994), pp. 1-145, at p. 90.

${ }^{54}$ In Italy the system of censorship was separate from the system of printing privileges; see A. Nuovo, The Book Trade in the Italian Renaissance, trans. L. G. Cochrane (Leiden, 2013), pp. 237-44.

55 Koppitz, 'Die Privilegia impressoria', pp. 195-6; Maclean, Scholarship, Commerce, Religion, p. 144. 


\section{Stephen Rose}

to imperial constitution. ${ }^{56}$ The privileges granted in 1603 and 1616 to the Hamburg publishers Philipp de Ohr and Georg Ludwig Frobenius for the music of Hieronymus Praetorius went further: presumably because Praetorius was a Protestant, the 1603 privilege instructed 'that the songs should contain nothing in the preface or in the texts that is scandalous or opposed to Roman Catholic orthodoxy, or to the imperial constitution'. ${ }^{57}$ A similar wording is found in Frobenius's 1616 privilege. Praetorius's published collections contained Latin liturgical texts that would not offend the censor; indeed, several of these collections were subsequently reprinted in the strongly Catholic territory of Antwerp. ${ }^{58}$ By contrast, imperial privileges written in German for such musicians as Schütz or Schop made no stipulation about the texts. Censorship attempts by the imperial chancery thus seem to have been sporadic, and may have stemmed from the heightened confessional sensitivities in the decades around 1600 .

In Saxony the upper consistory used privileges to uphold the system of censorship that had developed since the 1570s. A 1594 edict commanded that books should be approved prior to publication by the theological faculties in Wittenberg and Leipzig. To assist this censorship process, it instructed that books should be published only in these two university cities or in Dresden, where publications could be supervised by the court preachers; a limited exception was made for the book trade in Freiberg. ${ }^{59}$ Indeed, several privileges - including those for Schein (1617 and 1628), Schultz (1622) and Hammerschmidt (1662) - instructed the composers to submit the texts of their works to the Leipzig theological faculty for approval before printing. ${ }^{60}$ In his 1617 application, Schein volunteered to send a manuscript of each future work to the Elector for approval (Appendix 3); nonetheless, a consistory member annotated the letter, saying that the privilege was granted on condition that the theological faculty censored the texts. ${ }^{61}$ Schütz's 1618 and 1627 privileges make no mention

${ }^{56}$ A-Wsta, Impressoria, Karton 27 , no. 46, fols. $481^{\mathrm{r}}-482^{\mathrm{v}}$; transcribed in Pohlmann, Die Frühgeschichte, pp. 272-3.

57 'Hac tamen specialiquoque lege adiecta: ut cantiones hae $<\mathrm{c}>$ tam in praefationibus, quam in contextu nihil quicquam scandalosum, aut adversum orthodoxae religioni Catholicae, vel etia $<\mathrm{m}>$ Imperii constitutionibus in se contineant.' A-Wsta, Impressoria, Karton 21, no. 32, fol. $232^{\mathrm{r}}$.

58 Phalèse reprinted Hieronymus Praetorius's Cantiones sacrae in 1622 (RISM A/I P5340) and his Missae in 1625 (RISM A/I P5332).

59 Gieseke, 'Die kursächsische Ordnung', p. 178.

${ }^{60}$ D-Dla, Loc. $10757 / 2$, fol. $59^{\mathrm{v}}$, 335 ${ }^{\mathrm{r}}$; Loc. $10757 / 3$, fol. $76^{\mathrm{r}}$; Loc. $10758 / 3$, fol. $34^{\mathrm{v}}$.

61 'Diss privilegium ist bewilligen, dass er die texten durch die theologische faculten in Leÿpzig censirt lassen.' D-Dla, Loc. 10757/2, fol. $61^{\mathrm{v}}$. 


\section{Protected Publications}

of censorship, but it is implied in his 1636 Saxon privilege, which states that his works are subject 'to the usual advance censor'. ${ }^{62}$ Further research is necessary to show how rigorously music was censored prior to publication. The Saxon system of censorship was shaped by the efforts of clergy and state in the 1570s to suppress Calvinism and promote Lutheran orthodoxy. ${ }^{63}$ Perhaps the censors treated polyphony with a light touch, because something so musically elaborate would inherently have had connotations of Lutheran orthodoxy.

A final way in which rulers asserted their power via the privilege system was in requiring holders of privileges to deposit, at their own expense, copies of the books thereby protected. Imperial privileges usually required the holder to submit between three and seven copies to the chancery: Schütz's 1637 privilege stated he should submit four copies of each book issued under its protection. ${ }^{64}$ Saxon privileges were more onerous, typically demanding eighteen copies from 1612 onwards despite the protests of bookdealers. ${ }^{65}$ Schein's 1617 privilege stipulated he supply eighteen copies of the first work issued under the privilege, and then nine copies of subsequent titles; Schütz's 1618 privilege required twelve copies of the initial publication and six copies of subsequent books. ${ }^{66}$ In his 1636 petition, Schütz tried to reduce this obligation, asking to submit just six copies of the Kleine geistliche Concerte if he published it himself, but twelve copies if a bookseller were the publisher. ${ }^{67}$ The upper consistory ignored his request, instead specifying in the privilege that he should submit eighteen copies of every publication. ${ }^{68}$ Although Schütz was evidently irked by the requirement for deposit copies, lesser-known musicians may have welcomed it as a way to draw their works to the attention of the Elector. If authors obeyed the stipulations on deposit copies, the Elector would have accrued countless books whose current location is unknown. One copy may have been placed in the

62 'auf vorhergehende gewöhnliche censur'. D-Dla, Loc. 10757/3, unfoliated privilege before fol. $406^{\mathrm{r}}$.

${ }^{63}$ H.-P. Hasse, Zensur theologischer Bücher in Kursachsen im konfessionellen Zeitalter: Studien zur kursächsischen Literatur- und Religionspolitik in den Jahren 1569 bis 1575 (Leipzig, 2000), pp. 69-182.

${ }^{64}$ Koppitz, 'Die Privilegia impressoria', 197; A-Wsta, Impressoria, Karton 61, Konvolut 1, no. 3 , fol. $6^{\text {r }}$.

65 J. Franke, Die Abgabe der Pflichtexemplare von Druckerzeugnissen mit besonderer Berücksichtigung Preussens und des deutschen Reiches (Berlin, 1889), pp. 81-5.

${ }^{66}$ D-Dla, Loc. $10757 / 2$, fols. $59^{\mathrm{v}}, 62^{\mathrm{r}}, 89^{\mathrm{r}}$. The initial draft of Schütz's privilege stated 18 deposit copies, a figure then revised downwards to 12 .

${ }^{67}$ D-Dla, Loc. 10757/3, undated autograph note inserted before fol. $406^{\mathrm{r}}$.

${ }^{68}$ D-Dla, Loc. 10757/3, unfoliated privilege before fol. $406^{\mathrm{r}}$. 


\section{Stephen Rose}

electoral library, and another in Leipzig's university library, ${ }^{69}$ but there would still have been a substantial quantity for the Elector to use as gifts or even re-sell. Perhaps the demand for so many deposit copies was primarily symbolic, an ostentatious show of the Elector's power over the applicant.

Many aspects of the application process for privileges can be read as ritualistic displays of princely power. Applicants had to abase themselves before the ruler as a quasi-protector, while submitting to the scrutiny involved in censorship. The surviving documents suggest that the process to gain a Saxon privilege was more elaborate than that for an imperial privilege. Petitions for Saxon privileges were typically longer and used more supplicatory language than those for imperial privileges; the fair copies of Saxon privileges (Figure 1 above) had a splendour rarely found in imperial documents. In the pomp of these documents and the demand for so many deposit copies, the Elector sought to outdo the Emperor in a competitive display of power and status. Musicians or booksellers seeking to protect their publications thus had to participate in this symbolic performance of a ruler's power.

\section{JUSTIFICATIONS FOR PRIVILEGES}

Despite the ritualistic nature of the process to obtain a privilege, the applications by composers reveal underlying ideas about musical authorship in the period. Composers claimed protection for their published works within a framework of loyalty to princely authority and to the wider community. The notion of Gemeinnutz (common good) was a prevalent ideology until the end of the seventeenth century, indicating how individuals should regulate their behaviour in the interest of the community. Gemeinnutz was opposed to Eigennutz (selfinterest), where an individual pursued his or her interests to the disadvantage (Schaden, Nachteil) of others. ${ }^{70}$ The ethic of Gemeinnutz was strengthened in Protestant lands by Luther's doctrine that believers should share their God-given talents for the benefit of their neighbours. Because of such beliefs, a composer's work was widely understood as common property (gemein), to be freely shared. Only princes could make an exception to this presumption of common property,

\footnotetext{
${ }^{69}$ Franke, Die Abgabe der Pflichtexemplare, p. 85.

${ }^{70} \mathrm{~W}$. Schulze, 'Vom Gemeinnutz zum Eigennutz: Über den Normenwandel in der ständischen Gesellschaft der Frühen Neuzeit', Historische Zeitschrift, 243 (1986), pp. 591-626.
} 


\section{Protected Publications}

via the granting of a privilege. ${ }^{71}$ The following section shows how privilege applications reconciled notions of the common good with recognition of the labour of composers and publishers.

The earliest printing privileges argued that these temporary interruptions of common law, guaranteeing the publisher or author a return on their publications, would nonetheless be for the public benefit. ${ }^{72}$ The first known privilege granted to a musician, the 1511 imperial privilege to Arnold Schlick, explained that his treatise on organ-building 'will reduce the high cost of organ-building caused from time to time by uncertain standards, by making this knowledge generally available to all in one book' ${ }^{73}$ To grant Schlick a ten-year privilege for his book was accordingly 'for the advancement of the common good' ${ }^{74}$ Another early imperial privilege, granted by Charles $\mathrm{V}$ in 1545 to the publisher Hans Ott for Heinrich Isaac's Choralis Constantinus, opens with a typical preamble. It praises 'those who strive to aid public studies at their own expense, labour and industry, and take it upon themselves that every book by good authors ... should be printed and published in the most accurate editions possible for distribution to the public'. Ott's publication of the Choralis Constantinus is described as an 'act of public beneficence', for which he deserved to be protected from pirate publishers 'who unjustly abuse the labour and industry of others for their own gain'.

In the decades around 1600, applicants for privileges still invoked the notion of the common good. Calvisius's 1594 application for a Saxon privilege for his Hymni sacri latini et germanici mentioned the hindrance caused by erroneous scribal copies, thereby implying the public benefit of having these hymns available in print. ${ }^{76}$ In his 1611 application for a renewed Saxon privilege, Calvisius explained: 'With this your Electoral Grace will promote the prosperous state of the Christian church and the profit of the studious youth ... and ... will increase my diligence to do other things that I hope will serve the

${ }^{71}$ Rose, Musical Authorship from Schütz to Bach.

72 Gieseke, Vom Privileg zum Urheberrecht, pp. 60-2.

73 'dardurch der mercklich vncosten. so bißher auf die werch der Orgeln jrer vnbestanndigkeit halben yezüzeitten gangen ist. verhütte werdt. in ainen druckh. solhs menigelich zü offen waren/ zü bringen willens sey.' Privilege printed in A. Schlick, Spiegel der Orgelmacher und Organisten (Speyer, 1511), sig. A2.

74 'sonnderlich zür fürdrung des gemainen nütz'. Ibid.

75 Translation from R. Gustavson, 'Commercialising the Choralis Constantinus: The Printing and Publishing of the First Edition', in D. J. Burn and S. Gasch (eds.), Heinrich Isaac and Polyphony for the Proper of the Mass in the Late Middle Ages and Renaissance (Turnhout, 2011), pp. 215-68, at pp. 264-5.

76 D-Dla, Loc. $7300 / 2$, Bd. 1, fol. $511^{\mathrm{r}-\mathrm{v}}$. 


\section{Stephen Rose}

common good' (Appendix 1). As late as 1662 Hammerschmidt explained that his Kirchen- und Tafel Music was intended to 'seek not mine, but God's honour and the profit of the Holy Church' (Appendix 6). Through such statements, composers claimed protection while avoiding accusations of self-interest.

Other applicants for printing privileges spoke of their desire to protect themselves from the reputational or financial damage caused by unauthorised editions. Typically they castigated the makers of such illicit editions as motivated by greed (Geitz) or self-interest (Eigennutz), and as seeking to cause disadvantage (Schaden, Nachteil) to the author. Several composers claimed in their privilege applications that their reputation would be damaged by misprints in unauthorised editions. In his 1617 petition for a Saxon privilege, Schein warned that 'many times, carefully disseminated things among others are liable to be reprinted by others with mistakes, not without special prejudice and disadvantage to the author' (Appendix 3). When applying for an imperial privilege, Lassus explained why composers should supervise their publications: 'Particular care must be taken lest books of music appear corrupted or poorly corrected, for whereas with ordinary books it may be possible for anyone to correct the mistakes, it is not easy for anybody to succeed in acting as corrector for misprinted songs. ${ }^{77}$ He went on to declare: 'For the first edition [the printers] are following my will closely, but afterwards where my works are reissued, either they follow their own taste or they abandon the care they previously showed, so I can barely recognise my own work. ${ }^{78}$ James Haar regards Lassus's comment as an example of 'the rhetorical vividness for which his music was celebrated', ${ }^{79}$ yet his fears were arguably justified. As shown below, unauthorised editions often contained misprints. Errors in partbook editions might not be spotted until the music was performed, and then it might be unclear whether the resulting harmonic clashes were caused by misprints or by the composer's incompetence.

Composers also argued that a privilege would protect them financially from unauthorised editions. Such concern was expressed mainly

\footnotetext{
77 'tum vero maxime singulari cura cavendum, ne libri Musici corrupte incorrecteve in lucem prodeant. Nam ut in caeteris fortasse aliquis vitia emendare posse videatur, tamen in cantionibus depravatis correctorem agere non cuiusvis esse facile evincitur.' Musée royal de Mariemont, Inv. Aut. 1112/4; quoted in Vanhulst, 'Lasso et ses éditeurs', p. 95.

78 'Nam ut prima aliqua vice vel maxime agant ex voluntate mea, postmodum ubi recudenda sunt opera mea, vel sibi ipsis morem gerunt solum, vel a prima sua diligentia ita recedunt ut quod meum prius fuerat, vix agnoscam statim.' Ibid.

79 Haar, 'Orlando di Lasso', p. 141.
} 


\section{Protected Publications}

by composers who acted as their own publisher and wished to recoup the capital they had invested in a run of copies. ${ }^{80}$ Many of the privilege holders listed in Tables 1 and 3 were self-publishers. In 1617 Schein sought his first Saxon privilege as he embarked on the publication of his own music, explaining that he had resolved to avoid working with commercial booksellers on account of their 'unreasonable' and 'selfinterested' behaviour (Appendix 3). The following year Schütz explained in detail the financial risk borne by self-publishers, in his application for a privilege for his Psalmen Davids (1619). As a novice to the publishing business, Schütz fretted that 'on completion of the opus, experienced booksellers and printers might immediately undertake to publish, reprint and sell it; consequently my copies might remain unsold and cause me significant and considerable harm' ${ }^{81}$ A privilege, he explained, would make him 'better able to recoup the effort and considerable expense'. ${ }^{82}$ Although Schütz may have received financial support from the Elector of Saxony (the dedicatee), publication of the Psalmen Davids was undoubtedly a substantial investment: each complete copy comprised thirteen partbooks with a total of approximately 850 pages, and a print run of at least several hundred copies is plausible. ${ }^{8}$

Vivid detail on why self-publishers needed the protection of privileges was offered by Hammerschmidt in his 1662 application for a Saxon privilege for his Kirchen- und Tafel Music: 'There might be selfish people who ... would reprint my work and sell it, through which not only my great labour would be turned to water, but also at the worst I would be ruined.' He reinforced his plea by claiming that his expenses exceeded 600 florins 'and I must therefore myself go back and forth into debt' (Appendix 6). The Kirchen- und Tafel Music is another large publication, comprising nine partbooks with a total of 680 printed pages; a sum of 600 florins would be equivalent to the retail cost

${ }^{80}$ On self-published music in this period, see S. Rose, 'The Composer as Self-Publisher in Seventeenth-Century Germany', in E. Kjellberg (ed.), The Dissemination of Music in Seventeenth-Century Europe: Celebrating the Düben Collection (Bern, 2010), pp. 239-60.

81 'nach verfertigung des operis, geübte buchhändtler vndt drucker vntterstehen, daßelbe also baldt aufzulegen, aufs newe widrumb nachzudrucken, vndt ferner zuvorhandlen, dannenhero mir dann meine exemplaria, ersitzen bleiben, vndt mercklicher großer schade, zugefügt werden möchtte'. D-Dla, Loc. 10757/2, fol. $85^{\mathrm{r}}$.

82 'auch meiner müh vndt ziemblichen großen vncosten, desto baß [besser] wieder beÿkommen möge'. Ibid., fol. $85^{\mathrm{v}}$.

83 Documented print runs for German partbook editions in the early seventeenth century range from 400 to 1000 copies; see S. Rose, 'Music Printing in Leipzig during the Thirty Years' War', Notes: Quarterly Journal of the Music Library Association, 61 (2004), pp. 323-49 at pp. 342-3. 


\section{Stephen Rose}

of approximately 600 partbook editions, and implies a print run somewhere between that number and one thousand copies. ${ }^{84}$ Hammerschmidt's concern about unauthorised editions preventing him recouping his costs was a legitimate one: all his other works were published by commercial booksellers and often appeared in several editions, indicating a strong demand for his music.

The link between self-publishing and privileges suggests that musicians sought protection for their publications as business ventures, rather than from a nascent sense of intellectual property. Pohlmann, by contrast, interpreted a limited selection of privilege applications as early examples of authors asserting their economic rights to profit from their intellectual property. Examining a 1598 application for a Saxon privilege by the Thuringian composer Johann Steuerlein, Pohlmann asserted: 'Here the relevant consideration is that the author by rights must reap the economic fruits of his intellectual work, and should not thereby be exposed to any injury or loss of rights. ${ }^{85}$ Yet Steuerlein was concerned to recoup the costs of printing, and showed no sense that his compositions were the products of his intellect. Near the start of his petition he reported (with reference to his previous publications): 'I have had to pay a fee to the printer, generally 1 thaler for each sheet, as is usual. ${ }^{86}$ (Interestingly, Steuerlein's previous works do not name him as publisher, merely indicating the name of the printer; ${ }^{87}$ his petition suggests that composers had to contribute to the costs of typesetting and printing even when not named as publisher on the title page) ${ }^{88}$ Steuerlein continued in his petition to the Elector: 'With your princely reputation and authority ... and by means of a privilege transmitted from your princely grace to me ... I would humbly like to taste the profit from my musical work, and thereby remain unscathed by the printer's fees. ${ }^{, 89}$ 'Musical work' could refer to

${ }^{84}$ See n. 40 for evidence of the possible retail costs of partbook editions.

85 'Hier ist der Gesichtspunkt tragend, daß der Autor billigerweise auch die wirtschaftlichen Früchte seiner geistigen Arbeit ernten müsse und hierbei keiner Schädigung und Rechtsverletzung ausgesetzt sein dürfte.' Pohlmann, Die Frühgeschichte des musikalischen Urheberrechts, p. 212.

86 'Ich habe aber bemelte jhar vber, vor jedem bogen, meistes theils, dem typographo, allweg ein thaler, zu truckgebuer entrichten müssen, wie dann gewöhnlich.' Thüringisches Staatsarchiv, Meiningen, Hennebergica Weimar, Akten Nr. 679, fol. $1^{\mathrm{r}}$.

${ }^{87} \mathrm{~J}$. Steuerlein, XXI geistliche Lieder (Erfurt, 1575); Deutsche Passion (Erfurt, 1576); XXIIII Cantiones sacrae (Erfurt, 1578), RISM A/I S6030, 6031, 6033.

${ }^{88}$ For a similar example, the Dresden court musician Antonio Scandello had to pay for the paper and printing costs of his Nawe schöne ausserlesene geistliche deudsche Lieder (Dresden, 1575), RISM A/I S1155. D-Dla, Kopiale 407 (1575), fol. 12v.

89 'mit ihrer fürstlichen reputation vnd auctoritet, meine musicalische arbeit . . . damit vermittelst Euer F<ürstlich〉e G<nad〉e mir gnedigst mittheilendten privilegij . . . ich 


\section{Protected Publications}

either his published opus or the labour he invested in preparing this publication; either way, he sought protection specifically with regard to publication, not as recompense for the creative act.

Pohlmann made a similarly anachronistic interpretation of Melchior Vulpius's 1601 privilege application as articulating 'the imminent legal awareness of the human creator'. ${ }^{90}$ He focused on Vulpius's statement that 'my work is not for my private hoarding, and I am hoping through it to earn a modest crust of bread for me and my family'. ${ }^{91}$ But here again, Vulpius was concerned specifically about the costs of printing: 'As everyone knows, my income cannot stretch in the slightest to the printing of a publication. ${ }^{, 92}$ Whether because of modesty or a deep-seated view that true creativity belonged to God, composers never mentioned their intellectual abilities as justifications for their privileges.

Although privileges are often associated with composers who published their own music, some musicians obtained privileges for books issued by commercial firms. This was the case with Calvisius, who in 1594 and 1611 applied for Saxon privileges for hymnals he had edited. In his 1594 application he argued that a privilege 'would secure gratification [ergetzung] for my expended labour'. ${ }^{93}$ The term Ergötzungwas used in publishing contracts to refer to the author receiving either a lump-sum payment in exchange for the copy-text, or a set of free copies. ${ }^{94}$ Calvisius clarified his meaning in his 1611 application for a renewed Saxon privilege (Appendix 1). Here he claimed he had not received Ergötzung for the third edition of his hymnal Harmonia cantionum ecclesiasticarum, which was published in 1605 by Jakob Apel, after the expiry of his earlier privilege. He noted that all the copies

desselben vnderthenigst nützbarlich genießen, vnd also hinfüro, der trückgebühr dardurch verschont bleiben möge'. Thüringisches Staatsarchiv, Hennebergica Weimar, Akten Nr. 679, fol. $1^{\mathrm{v}}$.

90 'das immanente Rechtsbewußtsein des schöpferischen Menschen'. Pohlmann, Die Frühgeschichte des musikalischen Urheberrechts, p. 212.

91 'zu meinem schatz od<er〉 vorrath nichts denn meine arbeit, vnd hoffend bin ich wolts dadurch mihr vnd den meinen ein geringes stucklein brots zu wegen bringen .... D-Dla, Loc. $08844 / 4$, fol. $177^{\mathrm{v}}$.

92 'Wann aber iederman bewust, das mein vermögen den verlag zu trucken sich im geringsten nicht erstrecket.' Ibid., fol. $177^{\mathrm{r}-\mathrm{v}}$.

93 'mir zu ergetzung gehabter arbeit gereichen würde'. D-Dla, Loc. 7300/2, Bd. 1, fol. $511^{\mathrm{v}}$.

94 A. Kirchhoff, 'Ein Verlags-Contract vom 1604 mit einer Art Gewinnbetheiligung des Verfassers', Archiv für Geschichte des deutschen Buchhandels, 18 (1895), pp. 244-7. A 1627 publishing contract from Leipzig stipulated that the bookdealer Paul Helwig should pay the heirs of the theologian Friedrich Balduin for his Prophetia Apostolica, hoc est, S. Apostoli Pauli Utraq[ue] Epistola Ad Thessalonicenses as follows: for the first edition, 11/2 Reichsthaler for each printed sheet (Bogen) in the book (to be paid after the first Leipzig book fair after the book was printed), plus fifty copies; for subsequent editions, 6 groschen per printed sheet, plus twenty-four copies. A. Kirchhoff, 'Lesefrüchte aus den Acten des städtischen Archivs zu Leipzig', Archiv für Geschichte des deutschen Buchhandels, 15 (1892), pp. 189-297, at pp. 192-6. 


\section{Stephen Rose}

had been sold by the publisher, perhaps implying he had expected to be rewarded with gratis copies. ${ }^{95}$ Echoing his 1594 application, he claimed that renewal of his privilege for the fourth edition of his hymnal 'will secure me gratification for my expended labour' (Appendix 1). For books such as hymnals with strong commercial potential, a privilege may have helped a musician negotiate a material reward from the publisher.

Yet this financial recognition was earned neither by intellectual effort nor by an act of creation. In Calvisius's applications for privileges, the term Arbeit referred to his labour as an editor and arranger: indeed, the title page of his Harmonia cantionum ecclesiasticarum described his role as setting the tunes 'in four voices in contrapuntal style correctly' and bringing them together 'in good order'. ${ }^{96}$ That arrangements could be protected by a privilege is further confirmed by the 1624 imperial privilege obtained by the Würzburg publisher Johann Volmar, for the figured-bass part made by the organist Caspar Vincentius for Lassus's Magnum opus musicum (1604). Vincentius was not the author of the 516 motets contained in the Magnum opus musicum. But he must have invested considerable labour in making the figured-bass part, a task for which he would have had to intabulate or score up all of the 516 motets in order to discern their harmonies.

The applications for privileges show that, contrary to Pohlmann's teleological interpretations, these legal instruments were not recognitions of authorship in terms of creative or intellectual work. Rather, privileges could be granted to publishers, editors, arrangers and composers alike. The main justifications for privileges were whether the publication served the common good, and whether the applicant had invested time or money in the volume. Self-publishers often applied for privileges to protect their works; and although their petitions cannot always be taken at face value, they offer tantalising glimpses of the transactions and costs involved in printing music.

\section{PRIVILEGES FOR POSTHUMOUS PUBLICATIONS}

A significant number of imperial and Saxon privileges were for posthumous publications of music. The family of a deceased composer sometimes sought to publish his works, either as a memorial to his achievements or as a source of income. Sheet music was often one of

95 The third edition of Calvisius's Harmonia cantionum ecclesiasticarum (RISM B/VIII DKL: $1605^{14}$ ) still lists a privilege on its title page.

96 'Mit Vier Stimmen contrapuncts weise/ richtig gesetzt/ vnd in gute Ordnung zusammen gebracht/ Durch Sethum Calvisium'. 


\section{Protected Publications}

the most valuable items in a musician's estate, and income from its sale could provide for the widow or other family members. (Indeed by the late seventeenth century it had become the norm for the widows of cantors to sell their deceased husband's music manuscripts to the town council that employed him) ${ }^{97}$ Because privilege applications were concerned with questions of ownership, they often indicate who initiated posthumous publications. Among the privileges analysed in the following section, those for posthumous works by Schein and Adam Krieger are of particular interest, because they reveal the role of female relations in arranging the publication of a deceased composer's music.

Privileges for posthumous publications of music show the range of individuals responsible for such projects. Given the importance of patrilineal inheritance, it might be expected that the sons of composers often supervised posthumous editions. Thus in 1628 an imperial privilege was granted to Johann Christoph Roberti, organist and musician in the Black Forest town of Hüfingen, for eight books of sacred music prepared by his father Heinrich for publication, as well as three books of his own compositions. ${ }^{98}$ In other cases, however, the privilege holder had a more distant connection with the deceased. Abraham Ratz's 1594 Saxon privilege covered, among other items, music by the late Paul Coler, for whose children Ratz was guardian. ${ }^{99}$ The imperial privilege of 1600 for the posthumous works of the Silesian musician Johann Knöfel was awarded to Matthias Herr, a messenger for the Silesian chamber (the administrative organ through which the Emperor imposed Habsburg rule on Silesia). ${ }^{100}$ The privilege stated that Herr intended to have a selection of Knöfel's Latin and German works printed by Paul Kauffmann in Nuremberg. Perhaps the acquisition of a privilege was delegated to Herr in his role as a go-between between the Emperor and the Silesian lands that were Knöfel's home.

${ }^{97}$ P. Wollny and C. Wolff, 'Allgemeine Strategien in Bachs 1. Leipziger Kantatenjahrgang: Einleitung', in M. Geck (ed.), Bachs 1. Leipziger Kantatenjahrgang. Bericht über das 3. Dortmunder Bach-Symposion 2000 (Dortmund, 2002), pp. 23-40, at pp. 24, 34.

98 A-Wsa, Impressoria, Karton 60 , no. 1 , fols. $1^{\mathrm{r}}-6^{\mathrm{r}}$.

99 D-Dla, Loc. 07301/01, fols. $388^{\mathrm{r}}-389^{\mathrm{v}}$.

${ }^{100}$ A-Wsa, Impressoria, Karton 29, no. 57, fols. $423^{\mathrm{r}}-425^{\mathrm{v}}$. This privilege shows that Knöfel had died by 1600 , whereas most modern reference books state his death date as 'after 1617' (see L. Hübsch-Pfleger, 'Knöfel, Johann', Grove Music Online, www.oxfordmusiconline.com, acc. 14 Nov. 2016; H. Möller, 'Knöfel, Johann', Musik in Geschichte und Gegenwart. Personenteil, x (Kassel, 2003), cols. 347-9). Sources favouring the later date cite a reward paid to a musician of this name by the Klagenfurt council (H. Federhofer, 'Beiträge zur älteren Musikgeschichte Kärntens', Carinthia I: Mitteilungen des Geschichtsvereins für Kärnten, 145 (1955), pp. 372-409, at p. 405). However, the name 'Knöfel' is relatively common, so the Klagenfurt document probably refers to a different individual. 


\section{Stephen Rose}

Newly discovered archival records for Saxon privileges show the negotiations involved in the posthumous publication of Schein's music. During his lifetime Schein acted as his own publisher for nine collections of his music: two volumes of sacred concertos (Opella nova, 1618, 1626); madrigals with spiritual texts (Israelis Brünlein, 1623) and secular texts (Diletti pastorali, 1624); three volumes of secular villanellas (Musica boscareccia, 1621, 1626, 1628); a book of student songs (Studenten-Schmauß, 1626); and a hymnal (Cantional, 1627). Several of these books appeared in repeat editions during his lifetime. In his 1628 petition to renew his Saxon privilege, Schein outlined his intention to publish a large book of sacred music (with concertos for one to twelve voices), and also described the difficulties he met as a selfpublisher (Appendix 4). Corroborating a complaint he made in Opella nova Ander Theil (1626), ${ }^{101}$ he grumbled that his business was undermined by booksellers who refused to stock his books or even acknowledge their existence. The bookdealers may have been reluctant to deal with Schein because he was not a guild member or because he could not participate in the exchange trade (Tauschhandel) that was the basis of wholesale transactions. Schein's complaints about his difficulties selling his work without access to a bookshop may explain why his widow did not continue his business after his death.

On Schein's death in 1630, his widow sold his considerable stock of publications to the Leipzig bookdealer Jakob Schuster, along with the copperplates for the engraved title pages (Appendix 5). Already in 1634 Schuster issued a new edition of Schein's drinking songs, the Studenten-Schmau $\beta$ (see Table 5). In 1641 Schuster gained an eight-year Saxon privilege for new editions of Schein's works. In his application (Appendix 5), he explained that the copies he had bought from the composer's widow were now all sold, and he wished to meet the ongoing demand for Schein's music by publishing new editions. To justify the privilege being granted to him rather than the family, he noted that the composer's privilege had expired on 17 November 1638, and that he had bought the opera musica from Schein's heirs.

As Table 5 shows, during the duration of Schuster's 1641 privilege he issued new editions of Studenten-Schmau $\beta$, the Cantional, and all three parts of Musica boscareccia. The new edition of the Cantional retained the octavo format of the 1627 edition, despite Schuster stating in his privilege application that he wished also to issue it in duodecimo and octodecimo. It was enlarged with twenty-seven further sacred songs, mostly

101 J. H. Schein, Opella nova. Ander Theil (Leipzig, 1626), Basso Continouo partbook, Avvertimento. 


\section{Protected Publications}

Table 5 Posthumous editions of Schein's music published by Jakob Schuster, ordered chronologically

\begin{tabular}{|c|c|c|c|c|}
\hline Date & Title & $\begin{array}{l}\text { Printer and place } \\
\text { of printing }\end{array}$ & RISM A/I ID & $\begin{array}{l}\text { Advertised in } \\
\text { Leipzig book } \\
\text { fair catalogues }\end{array}$ \\
\hline 1634 & $\begin{array}{l}\text { Studenten- } \\
\text { Schmau } \beta\end{array}$ & $\begin{array}{l}\text { Henning Köler } \\
\text { (Leipzig) }\end{array}$ & S1396 & \\
\hline 1641 & $\begin{array}{l}\text { Studenten- } \\
\text { Schmau } \beta\end{array}$ & $\begin{array}{l}\text { Wolff Seyffert } \\
\text { (Dresden) }\end{array}$ & SS1396a & Spring 1645 \\
\hline 1641 & $\begin{array}{l}\text { Musica } \\
\quad \text { boscareccia II }\end{array}$ & $\begin{array}{l}\text { Wolff Seyffert } \\
\text { (Dresden) }\end{array}$ & S1393 & $\begin{array}{r}\text { Autumn 1643; } \\
\text { spring } 1645\end{array}$ \\
\hline 1643 & $\begin{array}{l}\text { Musica } \\
\quad \text { boscareccia III }\end{array}$ & $\begin{array}{l}\text { Wolff Seyffert } \\
\text { (Dresden) }\end{array}$ & S1403 & $\begin{array}{r}\text { Autumn 1643; } \\
\text { spring } 1645\end{array}$ \\
\hline 1643 & $\begin{array}{l}\text { Musica } \\
\quad \text { boscareccia I }\end{array}$ & $\begin{array}{l}\text { Wolff Seyffert } \\
\text { (Dresden) }\end{array}$ & S1383 & $\begin{array}{r}\text { Autumn 1643; } \\
\text { spring } 1645\end{array}$ \\
\hline 1645 & Cantional & $\begin{array}{l}\text { Timotheus Ritzsch } \\
\text { (Leipzig) }\end{array}$ & S1398 & Spring 1645 \\
\hline 1650 & $\begin{array}{l}\text { Studenten- } \\
\quad \text { Schmau } \beta\end{array}$ & $\begin{array}{l}\text { Heirs of Timotheus } \\
\text { Hön (Leipzig) }\end{array}$ & $\begin{array}{c}\text { Not in RISM; copy } \\
\text { at D-W, L 294.4 } \\
\text { Helmst. (24-28) }\end{array}$ & Spring 1650 \\
\hline 1650 & Diletti pastorali & $\begin{array}{l}\text { Heirs of Timotheus } \\
\text { Hön (Leipzig) }\end{array}$ & $\begin{array}{l}\text { Not in RISM; copy } \\
\text { at PL-Kj, Mus. } \\
\text { ant. pract. S580 }\end{array}$ & Spring 1650 \\
\hline $1651-2$ & Israelis Brünlein & $\begin{array}{l}\text { Heirs of Timotheus } \\
\text { Hön (Leipzig) }\end{array}$ & S1386 & Autumn 1651 \\
\hline
\end{tabular}

five-part lieder written by Schein and printed in pamphlets for funerals in the late 1620s; there are also three funerary compositions by Tobias Michael, Schein's successor as Thomaskantor. Previous scholars have suggested that Michael prepared this revised edition of the Cantional. ${ }^{102}$ But Schuster's application for his privilege should prompt consideration of the role of Schein's widow, who presumably supplied him with the copies of the pamphlets containing the extra lieder.

In 1649 Schuster gained an eight-year renewal of his Saxon privilege for Schein's works. In his petition he explained he still held many copies of his earlier editions and he wished to protect these against unauthorised reprints; ${ }^{103}$ seeking continuity of protection, he applied

${ }^{102}$ G. S. Johnston, 'Revision and Compositional Process in the Funerary Lieder of Johann Hermann Schein's Cantional (1627)', Schütz-Jahrbuch, 24 (2002), pp. 101-22, at p. 102.

103 'Wann dann ich mich zubefürchten, wenn mir von obigen musicalischen wercken noch viel exemplaria vbrig, das nach endzug vorerwehnten gnädigst mir ertheilten privilegii 


\section{Stephen Rose}

for the new privilege three weeks before the old one expired. Under the aegis of his 1649 privilege, he issued not only another edition of Studenten-Schmau $\beta$, but also new editions of the five-voice madrigals Diletti pastorali and Israelis Brünlein (Table 5). Possibly these polyphonic collections were now in demand as churches and choirs restocked their libraries after the Thirty Years War. He still used the title-page copperplates he had purchased from Schein's widow, as shown by the engraving on the 1650 tenor partbook of Studenten-Schmauß, with Schein's distinctive 'IHS' motto. ${ }^{104}$ Schuster's business ceased in $1653,{ }^{105}$ but his activities up to this date indicate the ongoing demand for Schein's music. As in Italy, it appears that some polyphonic genres (particularly secular song) were still marketable several decades after their initial publication. 106

A final example of posthumous publication concerns the Dresden musician Adam Krieger, and again shows the role of female relations in publishing the works of deceased composers. Krieger was best known for his strophic songs, which were first published during his lifetime in the 1657 edition of Arien issued by the Leipzig bookseller Martin Maier. ${ }^{107}$ The Dresden archives indicate that Maier held a tenyear privilege for the Arien, granted on 23 November $1656 .^{108}$

On 30 June 1666 Krieger died at the age of 30. In 1667 and 1676 posthumous editions of his Arien appeared, augmented with extra songs and instrumental ritornelli for five-part ensemble. Musicologists have usually attributed the editorship of these posthumous publications to the Dresden court poet and librarian David Schirmer, whose commendatory verse appears in both editions. ${ }^{109}$ The archives show, however, that the 1667 edition was protected by a ten-year Saxon privilege granted that year to Krieger's mother Anna for the 'posthumous musical things of her

solche entweder nachgedruckt, oder ein ander mir nach dergleichen privilegio stehen möchte, dardurch mir dann ein vberaus gantzen schaden zugefugen werden wolte.' D-Dla, Loc. 10758/01, unfoliated.

104 D-W, L 294.4 ${ }^{\circ}$ Helmst. (24-28).

105 J. Benzing, 'Die deutschen Verleger des 16. und 17. Jahrhunderts: Eine Neubearbeitung', Archiv für Geschichte des Buchwesens, 18 (1977), cols. 1078-1322, at col. 1265.

106 S. Boorman, 'Thoughts on the Popularity of Printed Music in 16th-Century Italy', Fontes Artis Musicae, 48 (2001), pp. 129-44, at p. 134.

107 RISM A/I K2436

108 D-Dla, Loc. 10758/02, unfoliated.

109 Studies that attribute editorship to Schirmer include Arien von Adam Krieger, ed. A. Heuss, Denkmäler deutscher Tonkunst, Erste Folge, 19 (Leipzig, 1905), pp. xi, xx; W. Braun, Thöne und Melodeyen, Arien und Canzonetten: Zur Musik des deutschen Barockliedes (Tübingen, 2004), pp. 267, 304, 310, 312. 


\section{Protected Publications}

deceased son'. ${ }^{110}$ The privilege is also advertised on the title page of the 1667 edition, with the words: 'So nach seinem Seel. Tode erst zusammen gebracht/ und zum Druck befördert worden/ Mit Churf. Durchl. zu Sachsen \&c. Special-Privilegio, in 10. Jahren nicht nachzudrucken.' The same wording appears on the 1676 edition (issued by the Dresden bookdealer Martin Gabriel Hübner), indicating it too was protected by Anna Krieger's privilege. In 1678, shortly after the expiry of her privilege, Hübner himself obtained a privilege for Krieger's 'Musicalien in fol. ${ }^{111}$ Possibly Anna Krieger had now died and Hübner wanted to ensure ongoing protection for his edition.

The archives contain only the draft of Anna Krieger's privilege; there survives no application letter, which might have illuminated her motives or the negotiations involved in the publication of these posthumous editions. Nonetheless the privilege suggests that following Krieger's death, his music became the property of his mother. Rather than selling it outright to a publisher (as did Schein's widow), she instead sought to control the publication and perhaps gain income from it via her Saxon privilege. Anna Krieger may have been involved in the editing and collation of the posthumous editions, perhaps commissioning the additions to the 1667 edition and even the unsigned preface for this book.

Under any circumstances, the printing of a music book was a collaborative venture, involving multiple negotiations between composer, publisher, printer and bookseller. The role of women in these collaborations was usually hidden, owing to the convention that their names should not appear in print: many seventeenth-century books bear the imprint of the heirs (Erben) of a printer, without explaining that such firms were often run by the printer's widow or unmarried daughter. The privileges for posthumous publications reveal a further way in which women might participate in the music trade, by negotiating for the publication of compositions by deceased family members.

\section{PRIVILEGES VERS US PIRATES}

The question remains whether privileges offered effective protection against unauthorised editions. Because polyphonic music was an elite item for a relatively small market, there are only a few documented examples of collections with sufficient commercial appeal to attract

\footnotetext{
110 'ihres verstorbenen Sohnes Adam Krügers . . . hinterlaßene Musicalische Sachen’. Loc. 10758/04, unfoliated. The privilege confirms Moritz Fürstenau's unsubstantiated assertion that Krieger's mother was called Anna. See M. Fürstenau, Zur Geschichte der Musik und des Theaters am Hofe zu Dresden, 2 vols. (Dresden, 1861), i, p. 153.

${ }^{111}$ D-Dla, Loc. 10759/1, unfoliated.
} 


\section{Stephen Rose}

unauthorised editions. The following section examines how Schütz, Schein and Albert sought to use their privileges against pirate publishers.

Because of its complexity and technical demands on performers, Schütz's published music had limited commercial appeal. None of his authorised publications was sufficiently popular to appear in a second edition during his lifetime, apart from the simple four-voice hymns in his Becker Psalter (1628) that were subsequently published in editions of 1640 and 1661 sponsored by central German courts. ${ }^{112}$ Nonetheless Schütz's applications for privileges repeatedly refer to the threat of unauthorised reprints. In his 1642 request for the renewal of his imperial privilege, he declared: 'I stand in fear that someone might be found who would reprint my musical works for his own gain but at a great loss and disadvantage to me. ${ }^{113}$ Six years earlier, when petitioning for a renewed Saxon privilege, Schütz claimed that booksellers refused to publish his music because of "various difficulties, especially the troublesome and disadvantageous reprinting'. ${ }^{114}$ In the mid-1630s, however, an equally plausible reason would have been the shortage of paper and financial difficulties caused by the Thirty Years War. ${ }^{115}$

The only known examples of unauthorised publications of Schütz's music are in a two-volume anthology, the Geistliche wolklingende Concerte assembled by Nordhausen music-lovers and printed in Goslar in 1637-8. These volumes include Schütz's concerto 'Schaffe in mir Gott' for two voices and continuo (SWV 291) and a set of duos from the Historia der Auferstehung (SWV 50). ${ }^{116}$ They also contain two abridged versions of Schütz's polychoral psalms: 'Lobe den Herren' (SWV 39) in an arrangement for two voices and continuo, and 'Alleluja! Lobet den Herren' (SWV 38) reduced to three voices plus continuo, and now attributed to Andreas Oehme. ${ }^{117}$ Although the making of anthologies was an accepted practice in the book trade, the anonymous editors of

112 RISM A/I S2282, 2283, 2284.

113 ' [ich] stehe aber in denen sorgen, es durffte . . . sich iemandt finden, derselbe zu seinem nuz, mir aber zu großen schaden vnd nachtheil nachtrucken möchte.' A-Wsta, Impressoria, Karton 61, Konvolut 1, no. 3, fol. $1^{\mathrm{r}}$. Transcribed in Schütz-Dokumente, i: Schriftstücke von Heinrich Schütz, ed. M. Heinemann (Cologne, 2010), pp. 222-3.

114 'Vntter andern difficulteten, bevorab auch den besorglichen vnndt schädtlichen nachdruck'. D-Dla, Loc. 10757/3, unfoliated letter before fol. $406^{\mathrm{r}}$ (transcribed in Schütz-Dokumente, i, p. 195).

115 Rose, 'Music Printing in Leipzig', p. 331.

116 Fasciculus primus geistlicher wolklingender Concerten (Goslar, 1638), RISM B/I 1638 ${ }^{5}$, no. 50; Fasciculus secundus geistlicher wolklingender Concerten (Goslar, 1637), RISM B/I 1637², no. 12. The anthologies are discussed in W. Braun, 'Bemerkungen zu den "Nordhäusischen Concerten” von 1637/38', Schütz-Jahrbuch, 25 (2003), pp. 85-104.

117 Fasciculus primus, no. 52; Fasciculus secundus, no. 55. 


\section{Protected Publications}

the Geistliche wolklingende Concerte feared their appropriations might arouse the composers' ire. As they wrote in the dedication of the 1637 volume: 'We have presumed to print and publish [these concertos] without incurring the displeasure of the authors themselves, to whose distinguished works we intend no harm.'118

Schütz would have regarded the reprinting of 'Schaffe in mir Gott' as a breach of his Saxon privilege, given that it was taken from the first book of his Kleine geistliche Concerte, which had been published two years earlier under a ten-year Saxon privilege. He may also have considered the few-voiced arrangements of his polychoral psalms as detrimental to his reputation. However, his Saxon privilege would not necessarily have been enforceable against the Nordhausen anthologies, which claim on their title pages to be likewise covered by a Saxon privilege (possibly a false claim, as no corroboratory evidence survives in the archives). Instead Schütz sought an imperial privilege, possibly in direct response to the Nordhausen volumes. ${ }^{119}$ (The chronology of the relevant documents is not straightforward: the earliest Nordhausen volume has a dedication dated 25 March 1637, whereas Schütz's imperial privilege is dated 3 April $1637 .{ }^{120}$ Schütz therefore would have required advance warning of the Nordhausen volumes to have gained an imperial privilege so soon after their publication.) Schütz's imperial privilege invoked a higher authority than the purported Saxon privilege protecting the Nordhausen anthologies. But his imperial privilege may have had little more than symbolic power, for it was likely to be upheld only by the imperial book commission at the Frankfurt book fair.

Privileges again seem to have had limited effectiveness for Schein against unauthorised editions. Schein's music had stronger commercial appeal than Schütz's, as shown by the posthumous publication of his works discussed above. Particularly popular were Schein's secular villanellas in the three volumes of Musica boscareccia, which were reprinted in 1628 by Paul Ledertz in Strasbourg. Ledertz's editions reproduced closely the composer's authorised versions, except that they omit the engraved title pages and have no reference to a

118 'Haben dieselbe wir . . . zu öffentlichem Truck wie wir vermeinen/ ohne Vnwillen der Autoren selbst/ welcher vornehmen Operibus wir hiermit keinen Abbruch zuthun gemeinet'. Fasciculus secundus, Prima Vox, dedication (signed by 'etzliche der Music Liebhabere'), sig. A3 ${ }^{\mathrm{r}}$.

119 O. Wessely, 'Zwei unveröffentlichte Heinrich-Schütz-Dokumente', Musikerziehung, 7 (1953), pp. 7-10; W. Steude, 'Neue Schütz-Ermittlungen', Deutsches Jahrbuch der Musikwissenschaft, 12 (1967), pp. 40-74, at p. 64.

${ }^{120}$ A-W sta, Impressoria, Karton 61, Konvolut 1, no. 3. 


\section{Stephen Rose}

privilege. ${ }^{121}$ Ledertz probably believed he was acting legitimately, given that Schein's first Saxon privilege had expired the previous year. Moreover, it was accepted practice in the book trade to reprint a work to serve a different geographical market from the original publisher. But Schein complained bitterly about Ledertz's editions in his 1628 application to renew his Saxon privilege, describing them as causing him 'insuperable harm' (Appendix 4). Undoubtedly Schein was irked by the appearance of Ledertz's editions in the autumn 1628 book fair at Leipzig, where they were in direct competition with his own stock. ${ }^{122}$ But because he had let his 1617 Saxon privilege expire, Schein could not petition the Leipzig council to confiscate the copies of Ledertz's editions at the fair. Nor did his renewed Saxon privilege prevent Ledertz's heirs printing further unauthorised editions in 1632 of Musica boscareccia after Schein's death, and these copies were again advertised for sale at the Leipzig fair. ${ }^{123}$ An imperial privilege might have offered better protection, given that Strasbourg was under imperial control; but Schein's struggle against Ledertz shows the difficulty of enforcing a privilege across the fragmented jurisdictions of German-speaking lands.

The best-documented example of a mid-seventeenth-century musician clashing with pirate publishers is provided by the Königsberg organist Heinrich Albert. Albert's Arien (which he published himself between 1638 and 1650) comprise eight volumes of strophic songs, setting verse by poets such as Simon Dach and Robert Roberthin (who met in Albert's garden in an informal society dubbed the Kürbs-Hütte). ${ }^{124}$ The Arien were highly popular for several reasons. They were the first German song collections to be printed in score format, on elegant folio pages with eye-catching engravings on the title pages. The songs included an attractive mix of sacred and secular topics, plus some homage compositions written for dignitaries visiting Königsberg. The musical settings could be realised in a variety of ways,

${ }^{121}$ RISM A/I S1381, 1391 and 1401.

${ }^{122}$ Catalogus Universalis . . Verzeichnüß aller Bücher/ so zu Franckfurt in der Herbstmeß/ vnd Leipzigischen Michaelsmarckt dieses jetzigen 1628. Jahres . . zu befinden (Leipzig, 1628), sig. $\mathrm{C} 4^{\mathrm{v}}$.

${ }^{123}$ RISM A/I S1382, 1392, 1402; see Catalogus Universalis . . V Verzeichnüs aller Bücher/ so zu Franckfurt in der Herbstmeß/ ond Leipzigischen MichaelsMarckt dieses jetzigen 1632. Jahrs . . zu befinden (Leipzig, 1632), sig. C1 ${ }^{\mathrm{v}}$ (publisher stated as Caspar Dietzel); Catalogus Universalis ... Verzeichnüs aller Bücher/so zu Franckfurt in der FastenMeß/ vnd Leipzigischen Ostermarckt dieses jetzigen 1633. Jahrs . . z zu befinden (Leipzig, 1633), sig. $\mathrm{B} 4^{\mathrm{r}}$ (publisher stated as Ledertz's heirs).

${ }^{124}$ For studies of Albert's Arien from literary and musical perspectives, see A. J. Harper, German Secular Songbooks of the Mid-Seventeenth Century (Aldershot, 2003), pp. 83-110; Braun, Thöne und Melodeyen, pp. 172-9. 


\section{Protected Publications}

ranging from a singer self-accompanying on the keyboard, to a group of singers alternating with instrumental ritornelli. With such versatility, the Arien appealed to many burghers in the cities along the Baltic coast. Most of the eight volumes received second or third editions within a few years of their first publication, and the folio format was imitated by other songbooks such as Johann Weichmann's threevolume Sorgen-Lägerin (1648).

In June 1642 Albert obtained a privilege from the Elector of Brandenburg and Duke of Prussia: 'We Friedrich Wilhelm . . . command graciously and earnestly the printers and booksellers in all our electoral and inherited lands, that they should not print the Arien in any format, neither in whole nor in part, neither melodies nor texts within ten years, nor possess or sell [unauthorised] copies printed by others. ${ }^{125}$ Subsequently the privilege was ratified by Władysław IV Vasa of Poland, who held sovereignty over Prussia. ${ }^{126}$ The wording of the privilege overlooked the collaborative nature of the Arien, specifically the contribution of the poets such as Dach. By giving Albert the exclusive right to control the publication of the texts and tunes, the privilege recognised primarily his role in assembling and publishing the Arien, rather than his role as a composer.

In 1645 the first unauthorised edition appeared: the Poetisches LustGärtlein, a duodecimo book containing the texts of fifty-seven secular songs from books 1 to 5 of the Arien. ${ }^{127}$ Like most illicit editions, the LustGärtlein bears no place of publication and no publisher's name; according to a catalogue from the Leipzig book fair, however, the publisher was Andreas Hünefeld in Danzig, ${ }^{128}$ The book epitomised the spirit of appropriation and popularisation common in the transmission of secular song: it made the lyrics available in a pocketsized format, suitable for those who could not read music or could not afford Albert's folio books. The Lust-Gärtlein gives correct attributions for the authors of almost all of the poems, and omits the

125 'Wir Friederich Wilhelm ... befehlen derowegen gnädigst und ernstlich den Buchdruckern und Buchhändlern in allen unsern Chur- und Erb-Landen/ daß sie dieselbige in keinerley Format/ weder gantz noch zum theil/ weder Melodeyen noch Texte innerhalb 10 Jahren nicht nachdrucken noch von andern gedruckt feil haben oder verkauffen sollen.' Reprinted in Heinrich Albert, Erster Theil der Arien, 4th edn (Königsberg, 1652), sig. $A 1^{\mathrm{v}}$.

${ }^{126}$ For extracts from the Polish privilege, see ibid.

127 Poetisches Lust-Gärtlein, darinnen schöne anmuthige Gedichten, lustige Lieder, zur Anleitung guter Tugend $u$. höfflichen Sitten (Danzig, 1645). Yale University Library, Zg17 D11 645.

128 Catalogus universalis . . . Verzeichnüß aller Bücher/ so zu Franckfurt in der HerbstMeß/ auch Leipzigis. MichaelisMarckte/ dieses ietzigen 1645. Jahrs (Leipzig, 1645), sig. D4 ${ }^{\mathrm{r}}$. 


\section{Stephen Rose}

melodies that were Albert's authorial contribution to the Arien. Yet Albert considered it to be 'an unjust work' ${ }^{129}$ and a breach of his 1642 privilege that protected the texts of the Arien. Because Danzig was under Polish jurisdiction, it contravened the version of the privilege confirmed by the Polish king.

More serious for Albert were three pirated editions of 1648 that mimicked the folio format of his authorised editions, in a deliberate attempt to deceive buyers. These fake editions comprised the PoetischMusicalisches Lustwäldlein, containing the words and music of 144 songs from Albert's books 1 to $6 ;{ }^{130}$ an unauthorised edition of the Siebender Theil der Arien; ${ }^{131}$ and a pirated version of the Musicalische Kürbs-Hütte (a 1645 set of three-part compositions commemmorating the poetic circle that met in Albert's garden). ${ }^{132}$ To a casual buyer and even to some modern bibliographers, these editions might look genuine. ${ }^{133}$ They claim on their title pages to be printed in Königsberg and they contain forewords bearing Albert's name; an extant copy of the PoetischMusicalisches Lustwäldlein even has an engraved frontispiece depicting Mount Parnassus, reminiscent of the engraved title pages on Albert's authorised editions. ${ }^{134}$ Yet these editions give no information about the publisher, and in the spring 1648 book-fair catalogue the Lustwäldlein was ascribed to the fictitious bookseller 'Christian Castuben' of Christiana (Oslo). ${ }^{135}$ Furthermore they were inaccurately printed, with no vertical alignment of the barlines in the score. Evidently the pirate typesetter had followed the notational symbols in Albert's editions by rote, unaware that a score needs to be read vertically as well as horizontally.

Albert complained bitterly about the pirated editions, even issuing a bifolium pamphlet attacking the Lustwäldlein. ${ }^{136}$ Confirming the fears of Lassus and Schein about misprints in unauthorised editions (see above), he argued that the inaccuracies of these pirated editions

\footnotetext{
129 'eine ungerechte Arbeit'. Albert, Siebender Theil der Arien (Königsberg, 1648), sig. G1' .

130 GB-Lbl, G.62.b.(1.); D-Mbs, 2 Mus.pr. 231.

131 GB-Lbl, G.62.b.(3.); D-Mbs, 2 Mus.pr. 231\#Beibd.2.

132 GB-Lbl, G.62.b.(2.); D-Mbs, 2 Mus.pr. 231\#Beibd.3.

133 Gerhard Dünnhaupt's bibliography of Albert's output does not recognise the pirated Siebender Theil der Arien and Kürbs-Hütte as unauthorised editions; see his Personalbibliographien zu den Drucken des Barock, 2nd edn, 6 vols. (Stuttgart, 1990-3), i, pp. 170-90.

134 D-Mbs, shelfmark 2. Mus.pr.231.

135 Catalogus Universalis . . . Verzeichnüß aller Bücher/ so zu Franckfurt in der Fasten-Meß/ auch Leipzigischen Oster-Marckte/ dieses ietzigen 1648. Jahrs . . zu befinden (Leipzig, 1648), sig. C1 . The pirated Siebender Theil der Arien is an exception to this statement, in that the imprint on the title page audaciously reads 'Königsberg/ bey dem Autor'.

136 Heinrich Alberts/ abgenötigte/ Nachricht vnd Verwarnung/Wegen eines . . . Nachdrucks seiner Arien (Königsberg, 1648), bound into the copy of Albert, Achter Theil der Arien (Königsberg, 1650), GB-Lbl, G.61.
} 


\section{Protected Publications}

would damage his reputation. Regarding the 1645 Lustgärtlein, he claimed that 'not a single song-text, whether reprinted in Danzig or here in small format, can be read without finding a mistake, not to mention that the same people have altered entire words and hence suppressed the correct meaning of each song' ${ }^{137}$ Given the vagaries of early modern orthography, this was perhaps an exaggerated grievance; but more pertinent were his complaints about the errors in the 1648 editions. Besides listing misprints in specific songs, he bemoaned the lack of vertical alignment in the score: 'As is apparent already from the first song, this [compositor] must be an ignoramus, for he does not set a single bar correctly, as it should stand in a score. The evil man continues in this inept way until the end of all the songs. ${ }^{138}$ Afraid that these botched editions would expose him to the 'scolding and mockery of learned musicians', ${ }^{139}$ Albert declared: 'I protest solemnly, that I did not set the music in such confusion.' ${ }^{140}$

Equally irksome for Albert was the economic damage caused by the pirate publishers. Here he echoed Luther's denunciation of the makers of unauthorised editions: 'Seeking their own profit, they do not care for the accuracy of what they print . . . they just print it quickly, to make money. ${ }^{141}$ Albert similarly claimed that booksellers and printers were motivated by greed, 'which in disregard of their conscience, against the prohibition of high princes, yes even against our God, they have no scruple in doing disadvantage to their neighbour'. ${ }^{142}$ Elaborating these comments in his 1648 Verwarnung, he lambasted 'these greedy printers and booksellers who take away the reward for my musical work'. ${ }^{43}$ Here

137 'Wie dann nicht ein einiges Lied/ so wol die zu Dantzig/ als auch/ welche dieses Orts in klein Format nachgedruckt/ zu lesen ist/ da nicht Fehler drinnen zu finden seyn solten/ zugeschweigen/ daß selbige Leute unterweilen gantze Wörter geendert vnd damit des Liedes rechten Verstand verdrucket haben.' Albert, Siebender Theil der Arien (Königsberg, 1648), sig. G1 $1^{\mathrm{v}}$.

138 'Wie dann bald erscheinet aus dem Ersten Lied/ welch ein Vnwissender es muß gewesen seyn/ der fast nicht ein Tempus richtig/ als es in partitura stehen sol/gesetzet vnd geordnet hat; In welcher Vngeschicklicheit der böse Mensch bey nah in allen Liedern biß an das Ende geblieben ist.' Heinrich Alberts/ abgenötigte/ Nachricht ond Verwarnung, sig.):( $1^{\mathrm{r}}$.

139 'Schimpff vnd Spott bey gelährten Musicis'. Ibid.

140 'Ich protestire solennissimè, daß ich die Noten in solche Confusion nicht gesetzet'. Ibid., sig. $):\left(1^{\mathrm{v}}\right.$.

141 'Denn weil sie allein jren Geitz suchen/ fragen sie wenig darnach/ wie recht oder falsch sie es hin nachdrücken ... Sie machens hin rips raps/ Es gilt gelt.' Biblia: das ist: die gantze Heilige Schrifft/ Deudsch/ Auffs new zugericht. D. Mart. Luth. (Wittenberg, 1545), sig. A3 ${ }^{\mathrm{r}}$.

142 'Der Geitz/ wie er unter allerhand Leüte sich einschlieret/ also befällt er auch unterweilen erst die Buchführer vnd Buchdrucker/ welche mit hindansetzung ihres Gewissens / wider das Verbot hoher Potentaten/ ia selbst unsers Gottes/ kein bedencken tragen/ ihrem Nechsten schaden zu thun.' Albert, Siebender Theil der Arien (Königsberg, 1648), sig. G1 $1^{\mathrm{v}}$. 


\section{Stephen Rose}

again, 'work' (Arbeit) could denote the published product or the process of composing and compiling it.

Albert then articulated his notion of musical property, explaining that 'this my work, so to speak (with Nathan) is my own little sheep, which can give me milk and wool, [but] some greedy people who have many sheep and cattle want to take it away from me'. ${ }^{144}$ Here he invoked the parable told by Nathan (2 Samuel 12: 1-13), in which the rich man stole the poor man's only sheep. In the Old Testament, Nathan told this story to rebuke King David for murdering Uriah the Hittite and committing adultery with his wife Bathsheba. As adapted by Albert, the rich men are the unscrupulous booksellers who steal the composer's few publications. The pastoral analogy does not refer to Albert's authorial role, making no mention of mental or physical labour that might mark his metaphorical 'sheep' as his own. By comparing himself to a smallholder with livestock, Albert clarified his desire to subsist from his publications, while distancing himself from any connotations of commerce.

Albert's privileges provided some legal protection against the pirated editions. In 1648 he reported that his Polish privilege was upheld by the city council of Danzig, which confiscated unauthorised copies of the Lust-Gärtlein and interrogated a possible suspect, a bookdealer's servant from Rostock. ${ }^{145}$ The servant attested in a sworn testimony that he was unaware of the author's privilege, and that he did not have more than eight unauthorised copies. He claimed these copies were acquired from a journeyman printer (a group often suspected of involvement in book piracy). ${ }^{146}$ If Albert's report is true, it can be added to the list of known occasions when privileges were enforced against unauthorised publishers. ${ }^{147}$

In 1648 Albert also obtained a twelve-year imperial privilege for his Arien, ${ }^{148}$ but it is unclear whether or not this was upheld. Its jurisdiction

143 'etliche geitzige Buchdrücker vnd Buchführer ... den Lohn meiner Musicalischen Arbeit mir zu entziehen vnd weg zunehmen'. Heinrich Alberts/ abgenötigte/Nachricht, sig.):( ${ }^{\mathrm{r}}$.

144 'diese meine Arbeit/ so zusagen (mit Natan) mein einiges Schäfflein/ das mir Milch und Wolle geben könte/ wollen etliche Geitzige/ deren doch ieder sehr viel Schafe und Rinder hat/ mir wegnehmen.' Albert, Achter Theil der Arien, sig. H1 ${ }^{\mathrm{v}}$.

145 Heinrich Alberts/ abgenötigte/ Nachricht, sig.): $\left(2^{\mathrm{r}}\right.$.

146 On Gesellen-Exemplarien (journeymen's copies) as a cause of piracy, see A. Beier, Kurtzer Bericht von der nützlichen und fürtrefflichen Buchhandlung (Jena, 1690), p. 53.

147 These disputes include those between Caspar Peucer and Sigmund Feyerabend over the Chronicon Carionis (1568) and between Peter Kopf and Ernst Vögelin over a legal treatise (1595). Gramlich, 'Rechtsordnungen des Buchgewerbes', pp. 99-102.

148 A-Wsta, Impressoria, Karton 1, no. 7, fols. $25^{\mathrm{r}}-26^{\mathrm{v}}$; an excerpt is printed on the reverse of the title page of Albert, Achter Theil der Arien. 


\section{Protected Publications}

did not include the Prussian and Polish lands that were the main markets for his music and the probable location of the printer of the 1648 pirated editions. Nor did it prevent the Breslau musician Ambrosius Profe issuing in 1657 a two-volume octavo edition of the songs from books 1 to 6 of the Arien, reduced to a two-voice texture of cantus and bass. ${ }^{149}$ Although Albert had died in 1651, the imperial privilege remained in force until 1660 and forbade anyone from reprinting the Arien 'in larger or smaller formats'. 150

In his preface, Profe sought to legitimise his edition by emphasising how it served the common good. All the folio copies had sold out, he noted, yet many people still wished to buy them, and there was nobody except Profe willing to print further copies. He also argued that his octavo edition was 'better and more useful' (besser und nützlicher) than the folio format of Albert's songbooks, in which only the first verse of each song was provided as underlay, with the remaining strophes printed at the bottom of the page. Some musicians even copied out the songs with all the strophes underlaid, 'but with much complaint and annoyance. To save you such effort and work, I have put the words of each strophe under the melody. ${ }^{151}$ Through such arguments, Profe presented his edition as a legitimate enterprise that neither infringed the composer's printing privileges nor disadvantaged Albert's heirs.

Although the legal power of Albert's privileges was limited, they had symbolic force, investing his editions with authority. Such a statement of authority is found on the 1650 engraved title page of the Achter Theil der Arien, where the three eagles symbolise the rulers who granted Albert his privileges (Figure 2). In the centre, the double-headed eagle represents the Holy Roman Emperor; on the left, the eagle symbolising the Polish crown is identifiable from the heraldic sheaf of the Vasa dynasty; and on the right, the eagle representing the Elector of Brandenburg is identifiable by the 'FV' initials of Friedrich Wilhelm (ruled 1640-88). Above the eagles, light radiates from the Hebrew letters $\mathrm{YHWH}$, the divine

${ }^{149}$ Heinrich Albert Arien Erster Theil/ Darinnen die jenige Geistliche Lieder/ so in seinen 6. unterschiedenen Theilen vorhin in Folio gedruckt, ed. A. Profe (Leipzig, 1657); Heinrich Albert Arien Ander Theil/ Darinnen die jenige Weltliche Lieder/ so in seinen 6. unterschiedenen Theilen vorhin in Folio gedruckt, ed. A. Profe (Brieg, 1657). RISM A/I A641-2.

150 '[die Arien] durch Jemand . . . weder in größer- oder kleinerer Form/ nit nachgedruckt'. Quoted in Albert, Achter Theil der Arien, sig. $\mathrm{H1}^{\mathrm{v}}$. On the disputed question of whether privileges remained valid after the death of their holder, see Lehne, 'Zur Rechtsgeschichte der kaiserlichen Privilegien', p. 385.

151 'Aber mit vielem Beschwer und Verdruß. Solcher Mühe und Arbeit nun euch zu überheben/ hab ich die Texte/ oder ieden Vers/ unter die gesetzte Melodey und Noten.' Heinrich Albert Arien Erster Theil, ed. Profe, sig. A3 ${ }^{\mathrm{v}}$. 


\section{Stephen Rose}



Figure 2 Engraved title page of Heinrich Albert, Achter Theil der Arien (Königsberg, 1650). British Library, G.61. By permission of the British Library Board

authority from which these secular princes drew their power. Under the eagles' wings are stylised scenes that represent the poetic world of the Arien: on the left, a funerary procession entering the city gates, and on the right, a convivial garden scene with musicians around a table and a lutenist and female singer. The theme of protection is reinforced by the nesting hen in the lower foreground, whose chicks are surrounded by the text 'Sub his alis' ('under these wings'), an allusion to Psalm 90:4 and its promise of God's shelter. ${ }^{152}$ Just as the hen protects her chickens, so too do the princely eagles guard Albert's sense of ownership over his Arien. The eye-catching iconography reassured purchasers that this 
edition was authoritative, and warned pirate publishers to stay away from Albert's published work.

\section{O N CLUSION}

The archival evidence uncovered in this article shows that printing privileges, far from being the forerunners of the modern copyright system as Pohlmann claimed, were a way for publishers and authors to increase the value of their publications. For publishers (including composers such as Schein and Schütz who self-published), a privilege enhanced the financial worth of an edition, raising the likelihood of a return on their investment. Some privileges may indicate music with strong commercial value, such as the posthumous editions of secular songs by Schein and Krieger. Yet the privilege system also boosted the symbolic significance of printed books. Because privileges were time consuming and expensive to obtain, they advertised the effort that an author or publisher had invested in a book. Mention of a privilege on a title page implied that the book was an authoritative text, produced to a high standard and properly proofread.

The uses of privileges show the symbiotic relationship between commercial and symbolic value in early music publishing. From the early sixteenth century onwards, in the wider book trade there was a growing awareness that mechanical reproduction could diminish the aura of a text. ${ }^{153}$ In response, some printers or authors replicated the devices used to authenticate handwritten texts, such as seals and signatures. From 1524 Luther's approved editions appeared with the 'Luther rose' - his coat-of-arms comprising a rose with a cross and his initials. As he explained: 'This sign shall testify that such books as bear it have gone through my hands, for there is much illegal printing and corruption of books these days. ${ }^{154}$ Privileges similarly acted as authentication marks, giving the book an authoritative presence. The iconographical representation of Albert's privileges on his Achter Theil der Arien (Figure 2 above) signalled that this book could be trusted, and thereby reassured potential purchasers that the higher price of

${ }^{152}$ Psalm 90:4: 'In scapulis suis obumbrabit tibi et sub alis eius sperabis' (He shall cover thee with his feathers, and under his wings shalt thou trust).

${ }^{153}$ I borrow the term 'aura' from W. Benjamin, 'The Work of Art in the Age of Mechanical Reproduction', in W. Benjamin, Illuminations, trans. H. Zohn, ed. H. Ahrendt (New York, 1968), pp. 217-51, at p. 221.

154 'Dis zeichen sey zeuge/ das solche bucher durch meine hand gangen sind/ denn des falschen druckes vnd bucher verderbens/ vleyssigen sich ytzt viel.' Cited in H. Volz, 'Das Lutherwappen als "Schutzmarke", Libri, 4 (1954), pp. 216-25 (illustration 1). 


\section{Stephen Rose}

the composer's authorised publications was worth paying. ${ }^{155}$ Thus the symbolic power of a privilege could enhance the commercial value of a publication. The documents analysed in this article show not only the relationships between princely authority, composers and publishers; they also illuminate the interplay between commercial and symbolic factors in the music trade, and thereby clarify the motives behind music publishing in the late sixteenth and early seventeenth centuries.

Royal Holloway, University of London

${ }^{155}$ In a 1651 note to bookdealers, Albert explained that: 'My Arien are not as expensive to sell as people falsely claim' ('meine Arien mit nichten so thewr verkaufft werden/ als man fälschlich außgesprengt'). Albert, Dritter Theil der Arien, 3rd edn (Königsberg, 1651), sig. $\mathrm{Cl}^{\mathrm{v}}$. 


\section{Protected Publications}

\section{AP P E N D IX 1}

\section{Seth Calvisius's 1611 Application for a Saxon Privilege}

Seth Calvisius to Elector of Saxony, 12 September 1611. D-Dla, Loc. 10757/1, fol. $354^{\text {r-v }}$. Autograph. ${ }^{156}$

Durchleuchtigster, Hochgeborner, Gnedigster Churfurst vnd Herr[,] E<uren〉Churf<ürstlichen〉 Gn<aden〉 sind mein vnterthenigste gehorsambste dienste hochstes trewes fleißes, sampt meinem teglichen Vater vnser zu Gott, fur E<urer〉Churf<ürstlichen〉 Gn〈aden〉 gluckliche regierung ieder zeit zuvor.

Gnedigster Churfurst vnd Herr nach dem ich fur sechzehen jahren des Herren $\mathrm{D}$ <octor〉 Martini Lutheri vnd anderer gottfurchtigen leute gesenge, so in dieser landen kirchen gebreuchlich mit vier stimmen contrapuncts weise vbergesezt, vnd vnter dem tittel Harmoniæ Cantionum Ecclesiasticarum in offentlichen druck verfertiget, der meinung das nicht alleine in der hauskirche diese Christliche gesenge vnd [sic] Gottes furcht ofter gevbt, vnd die iugendt den anfang zu singen draus lernen konte, sondern, das man diese meine arbeit auch auf dorfern vnd in steten in der kirchen offentlich gebrauchen konte, als ist Gottlob meine arbeit so wol gerahten, das gemeldete Harmoniæ an vielen orten angenomen vnd gebraucht worden[.] Vber welche auch damals der Durchleuchtigste vnd Hochgeborner Furst vnd Herr, Herr Friderich Wilhelm Herzog zu Sachsen etc. vnd der Chur Sachsen Administrator hochloblicher gedechtnis mir ein privilegium vnter dem dato den 16 Aprilis Anno 94 gnedigst mitgeteilet welchs aber nun mehr lengst zum ende gelaufen vnd erloschen, darumb den auch der buchführer I [fol. 354 ${ }^{\mathrm{v}}$ ] Jacob Apell alhier seit der zeit gemelte Harmonias zum andern, vnd zum dritten mal ohn all mein ergetzung aufgeleget vnd die exemplaria distrahiret. Wen er aber iezund solche zum vierden mal aufzulegen in willens, vnd aber ich dieselbige mit etlichen Christlichen gesengen vermehret vnd sonsten an vielen orten der Christlichen kirchen, vnd studierenden iugen[d] zum besten verbeßert, als gelanget an E<ure〉Churf<ürstliche〉 Gn<aden〉 mein vnterthenigst vnd hoch fleißiges bitten, dieselbigen wolten gnedigst geruhen, gedachtes privilegium vber meine Harmonias Cantionum Ecclesiasticarum noch auf zehen kommende jahr zu renoviren, vnd confirmiren.

Befordern hiermit E〈urer〉 Churf<ürstlichen〉 Gn〈aden〉der Christlichen kirchen wolstand vnd der studierenden iugend nutz vnd gereicht mir zur ergetzung gehabter arbeit vnd sonsten meines fleißes so ich auf andere sachen, welche gemeinem besten meines verhoffens dienstlich, zulegen gesinnet. Vnd ich erkenne mich E<uren〉Churfürstlichen〉Gn〈aden〉 zu vntherthenigsten, gehorsamen diensten alle zeit verpflichtet. Datum Leipzig den 12 Septembris A<nn〉o 1611.

156 Transcriptions follow the conventions in W. Heinemeyer (ed.), Richtlinien für die Edition landesgeschichtlicher Quellen, 2nd edn (Marburg, 2000). 


\title{
Stephen Rose
}

\author{
E〈urer〉 Churf<ürstlichen〉 Gn<aden〉 \\ Vnterthenigster \\ Sethus Calvisius \\ Cantor zu S<ankt> Thomas in Leipzig
}

Translation:

Most illustrious, high-born, most gracious Elector and Lord, my most submissive humble service and my highest true diligence are before your Electoral Grace, together with my daily Lord's Prayer to God for your Electoral Grace's happy reign evermore.

Most merciful Elector and Lord, sixteen years ago I arranged the songs of Dr Martin Luther and other God-fearing people, as used in this territory's churches, for four voices in contrapuntal style, and printed and published them in the book titled Harmonia cantionum ecclesiasticarum, with the intention not only that these spiritual songs tending to the fear of God would be used more often in domestic worship, and that the youth could learn from them how to start to sing, but also that this my work could be used in public worship in village and town churches. Praise God that my work has been so successful that the Harmonia is accepted and used in many places. At that time the most illustrious and high-born prince and lord Friedrich Wilhelm of Saxony, the Saxon electoral administrator of blessed memory, granted me a privilege for it, dated 16 April 1594, but which long ago has ended and expired. For this reason the bookdealer Jakob Apel has subsequently printed a second edition of the aforementioned Harmonia and a third, without any gratification for me, and sold the copies. But now he intends to print a fourth edition of this book, and I have enlarged it with a number of Christian songs, and have improved it to the best of my ability in many places, for the benefit of the Christian church and the studious youth. Therefore may my most humble and diligent petition reach your Electoral Highness, that you might deign to renew and confirm the aforementioned privilege for my Harmonia for another ten years.

With this your Electoral Grace will promote the prosperous state of the Christian church and the profit of the studious youth, will secure me gratification for my expended labour, and especially will increase my diligence to do other things that I hope will serve the common good. And I acknowledge myself always as the most submissive, obedient servant of your Electoral Grace. Dated Leipzig, 12 September 1611.

Your Electoral Grace's most obedient servant,

Seth Calvisius

Cantor at St Thomas in Leipzig 


\title{
Protected Publications
}

\author{
A P P E N D I X 2
}

Michael Praetorius's 1614 Letter to Matthias Hoë von Hoënegg regarding his Application for a Saxon Privilege

Michael Praetorius to Matthias Hoë von Hoënegg, chief court preacher and councillor on Upper Consistory, 13 October 1614. D-Dla, Loc. 10757/1, fol. $539^{\mathrm{r}-\mathrm{v}}$. Autograph.

Ehrwirdiger Edler vndt Hochachtbarer, großgünstiger herr vndt mechtiger befürderer, vnderwegen $ß$ zwischen Torgow vndt Wittenbergk ist mir eingefallen, daß ich ein priuilegium haben muß zu meinem Sÿntagmate, denn eß würden sich baldt andere finden die $\mathrm{e} \beta$ liessen nachdrücken, derowegen bitte ich gantz vnterdienstlich E〈hrwürdiger〉 $\mathrm{E}\langle d$ ler〉 vndt $\mathrm{H}$ <och〉a<chtbarer〉 welden mein großgünstiger beförderer sein, daß ich vf die quatuor tomos ein priuilegium bekommen müchte[.] Ich müste eß aber kegen Martini geliebts Gott haben, der herr Michael Mölich wird die cantzelei gebühr außlegen. Meine andere schreiben habe ich zu Torgow gelaßen, hoffe E〈hrwürdiger $\mathrm{E}<$ dler $>$ vndt $\mathrm{H}<\mathrm{och}$ `a $<c h$ tbarer werden sie albereit bekommen haben aber noch bekommen, sonsten vor dießmahl nichtmehr den vnß allen dem lieben Gott befohlen, Datum Wittenbergk am $13^{\text {ten` }}$ Octobris An«n〉o 1614.

\section{E〈hrwürdiger $>\mathrm{E}<$ dler $>$ vnd $\mathrm{H}<\mathrm{och}>\mathrm{a}<\mathrm{ch}$ tbarer $>$ \\ Vnterdienstwillig allz<eit $>$ \\ M Prætorius $M<a n u>p<r o>p<r i a>$}

\section{Translation:}

Honourable, noble and highly esteemed, most favourable lord and mighty protector: on the way between Torgau and Wittenberg it occurred to me that I must have a privilege for my Syntagma [musicum], otherwise it will find itself soon reprinted by others. For this reason I request most humbly that your honourable, noble and highly esteemed lord (who is my most favourable patron) might most graciously permit my request for a privilege for the four volumes [of Syntagma musicum]. But I must have it around the time of St Martin's day, God willing; Herr Michael Mölich will pay the chancery fee. My other letters I left in Torgau, but I hope your honourable, noble and highly esteemed lord has already received them or will shortly receive them, otherwise there is nothing else at present but to commend us all to dear God. Dated Wittenberg on the 13th October 1614.

Honourable, noble and highly esteemed

Always willing to serve

M. Praetorius, in his own hand 


\section{Stephen Rose}

A P P E N D X 3

\section{Johann Hermann Schein's 1617 Petition for a Saxon Privilege}

Johann Hermann Schein to the Elector of Saxony, 1 July 1617. D-Dla, Loc. $10757 / 2$ [volume wrongly numbered $10757 / 3$ ], fols. $60^{\mathrm{r}}-61^{\mathrm{v}}$. Autograph.

Durchlauchtigster hochgebohrner Gnedigster Churfürst vndt Herr, E<uren〉 Churf<ürstlichen〉 Gn<aden〉 seindt meine vnterthanigste gehorsambste trewe dienste, bestes fleißes zuvorn.

Gnadigster Herr, E<urer〉Churf<ürstlichen〉 G«naden〉 gebe ich hiermit vnterthanigste zu vernehmen, welcher gestalt in deroselben hoff capellen, darinnen ich verruckter zeit, gantzer vier jahrlang vor einen discantisten vnterthanigst auffgewarthet, nicht alleine meine fundamenta in der composition geleget, sondern auch binnen solcher zeit benebenst andern meinen studien so fern exerciret vndt excoliret, daß ich durch Göttliche verleÿhung vnterschiedene opera ohne vngebührenden ruhm in öffentlichen druck publiciret vndt ausgehen lassen. Dannenhero von den Durchlauchtigen Hochgebohrnen Fürsten vndt Herrn, Herrn Johan Ernsten den Jüngern, Hertzogen zue Sachsen, Jülich, Cleve vndt Bergk, meinen auch gnadigen Fürsten vndt Herrn, zu I<hrer〉 F<ürstlichen〉 G<naden〉 hoff-music capellmeister nach Weimar ich vnwirdigst vociret vndt bestellet werden bin, welchen dienst ich dann mit zuvor vngereimbten, iedoch trewen fleiße, nach meinen hierzu von Gott verliehenen besten verstand, bis in das dritte jahr dermaßen vorgewesen, daß nicht allein $\mathrm{I}<\mathrm{hre}\rangle$ F<ürstliche> Gn<aden〉 mitt meiner vnwirdigen verrichtung wol I [fol. 60 ${ }^{\mathrm{v}}$ ] content vndt zufrieden gewesen, sondern auch mir hierüber ein schriftliches testimonium in gnaden ertheilen lassen, in deme nunmehr beÿ I<hrer〉 F<ürstlichen〉 $\mathrm{G} \ltimes$ naden〉 von einem erbarn rathe zu Leipzigk nach tödlichen abgang Sethi Calvisij, dero daselbsten studirenden jugent zum besten, zu ihren stadt musico vndt cantore ich vnterthanig außerbethen, vociret vndt bestellet worden bin.

Alldieweil ich dann nun gedachtes orthes nicht alleine die liebe music vermittelst Göttlichen beÿstandes $\mathrm{zu}$ einem wolstandt vndt auffnehmen zubringen verhoffe, sondern auch zu besten behuff mit meiner composition, alla moderna, fortzufahren, vndt dieselbe ich in E〈urer〉Churf<ürstlichen〉 Gn<aden〉 landen, weniglich zu nutz vndt musicalischer ergotzung, öffentlichen truck zu vntergeben, beÿ mir entschlossen, inmassen ich fur dieses mal etzliche geistliche deutzsche concerten à 3 voci col basso continuo per l'organo fur mich genommen, vndt weil wegen des verlags die buchführer etwas vnbillich vndt eigennützig, solche vndt andere meine musicalische sachen, künfftigk selbsten zu verlegen verursachet werde.

Vndt aber vielmahl wolabgesande sachen von andern, nicht ohne sonderliches praejudiis vndt nachtheil der authorn vitiose nachge- I [fol. $61^{\mathrm{r}}$ ] trucket zuwerd $<$ `n pflegen, wann sonderlichen deselben mit der hohen obrigkeit nicht muniret vndt befreÿet.

Als gelanget an E<ure〉Churf<ürstliche〉 Gn<aden〉 mein vnterthanigstes hochfleißiges bitten, dieselben geruhen gnadigst, mir nicht alleine vber 


\title{
Protected Publications
}

mehrgedachte itzo vorhabende concerten, sondern auch vber andere meine künfftige musicalische sachen, so ich ausgehen lassen möchte, ein privilegium zuertheilen, vff welchen fall dann, E〈urer〉Churf<ürstlichen〉 Gn<aden〉 ich zu ieden mahlen das manuscriptum vff gnädigstes begehren zutzuschicken, vndt dero von E<urer〉 Churfürstlichen〉 Gn<aden〉 hierzu verordneten judicio solches zu vntergeben, mich schuldigst erkenne.

Solches zu deme es Gott den Allmachtigen zu Ehren, E<ure Churf<ürstliche〉 Gn raden〉 Kirchen vndt Schulen zum besten, der auffwachsenden studierend[e]n jugendt zum exercitio vndt aufmunterung, vndt endlichen $\mathrm{zu}$ fortpflantzung vndt beförderung der lieben music selbsten gereichen thut. So bin auch vmb E<urer〉 Churf<ürstlichen〉 Gn<aden〉 ich es mit meinen gehorsambsten trewen diensten bestes fleißes nach eüssersten vermögen vnterthanigst zuverdienen iederzeit pflichtschuldigst vndt bereitwilligst, dat<um〉 Dresden, den 1. Julij A«nn〉o 1617

\author{
E<urer〉 Churf<ürstlichen〉 Gn<aden〉 \\ vnterthanigster gehorsambster \\ Johan Herman Schein \\ dieser zeit musicus vndt cantor zu Leipzig m<anu $p$ pro $>$ p ria
}

Translation:

Most illustrious, high-born, most gracious Elector and Lord, my most submissive and most obedient faithful service are before your Electoral Grace, to the best of my ability.

Most merciful Lord, I hereby most submissively bring to the attention of your Electoral Grace how in the past I most humbly served as a treble in your Grace's electoral court chapel for a full four years, during which time I not only gained the fundaments in composition, but also besides my other studies I exercised and polished these skills so far that (without unseemly boasting) with God's help I had various works printed and published. For this reason I was most unworthily called to Weimar and appointed by his Highness the Illustrious Prince and Lord, Lord Johann Ernst the Younger, Prince of Saxony, Jülich, Cleves and Berg, also my merciful prince and lord, as Kapellmeister of his Princely Grace's court music. I served in this position with unsystematic but faithful diligence, according to my best understanding granted to me by God for this purpose, for more than two years, so that his Princely Grace was not merely well contented with my unworthy service, but also graciously granted me a written reference about it. And while I was still in the service of his Princely Grace, I was humbly approached, invited and appointed, after the death of Seth Calvisius, by the honourable council of Leipzig, which itself sought the best for the studious youth, as their town musician and cantor.

Forasmuch in the aforementioned place I hope not only to bring the dear music (by means of Godly assistance) to a prosperous state, but also for the best convenience continue with my compositions in modern style. And I have resolved to print and publish the same compositions in your Electoral Grace's 


\section{Stephen Rose}

lands, at the least for utility and musical delight, inasmuch as I this time have undertaken for myself some sacred German concertos in three voices with basso continuo on the organ, and because the bookdealers are somewhat unreasonable and self-interested as publishers, I will cause this and my other musical things in future to be published by me.

But many times, carefully disseminated things among others are liable to be reprinted by others with mistakes, not without special prejudice and disadvantage to the author, especially when the same is not protected and privileged by higher authority.

Therefore may my most submissive and highly diligent petition reach your Electoral Grace, that you deign most graciously to grant a privilege to me not just for the previously mentioned concertos that are currently planned, but also for my other future musical things that I would like to issue. In this case then I dutifully promise each time to send the manuscript to your Electoral Grace, on gracious request, and submit the same to the judgement ordained by your Electoral Grace.

Such [a privilege] would redound to the honour of God the almighty, the betterment of Your Electoral Grace's churches and schools, the exercise and encouragement of the studious youth, and finally the cultivation and promotion of dear music herself. Thus I am, for Your Electoral Grace's sake, at all times very ready to serve most humbly with my most obedient and faithful service, to the best of my powers and according to my utmost ability. Dated Dresden, 1 July 1617.

\section{Your Electoral Grace's most submissive and most obedient Johann Hermann Schein}

Musician and cantor in Leipzig at the current time, in his own hand

\section{A P P E N D IX 4}

Johann Hermann Schein's 1628 Petition for a Saxon Privilege

Johann Hermann Schein to the Elector of Saxony, 13 November 1628. D-Dla, Loc. $10757 / 3$, fols. $77^{\mathrm{r}}-78^{\mathrm{v}}$. Autograph.

Durchlauchtigster Hochgebohrner Gnedigst<er〉 Churfürst, Gnedigster Herr, E<urer〉Churf<ürstlichen〉 Durchl<aucht〉 seindt meine vnterthenigste gehorsambste dienste bestes trewen fleißes zuvorn.

Gnedigster Herr, E<ure〉Churf<ürstliche〉 Durchl<aucht〉 erinnern sich gnedigst was an dieselben A«nn〉o 1617. weg〈en〉 eines privilegij vber meine musicalisch<en〉opera ich vnterthenigst supplicando gelang<en〉 lassen. Nun haben zwar E<ure〉Churf<ürstliche〉 Durchl<aucht〉 aus angebohrner Churf<ürstlicher〉 höchstgeneigter gnedigst<er $>$ affection zu der edlen music vndt deroselb<en〉 recht verstendig<en〉 cultorn meinem vnterthenigsten petit [i]o[ni] damals so weit stadt vndt raum gegeben, daß nemblich kein 


\section{Protected Publications}

buchhendler, noch drucker meine musicalische sachen, welche ich selbst<en〉 (aus angezogenen motiven) verlegen wurde, innerhalb den nehesten von damalig<en〉 vnte[r]n dato an folgend<en $>$ zehen jahren in d<er $>$ Chur- vndt Fürstenthumen Sachß<en〉 deßelb<en〉 incorporirt<en〉 land<en〉 vndt stifften, nachdrucken, noch auch, da dieselben an anderen ortten künff[t]ig gedruckt, darin verkauffen vndt verhandeln solte, beÿ verlust aller nachgedruckt<en〉 exemplarien, vndt einhundert goldguld<en〉straff, die dann zur helffte in E<urer〉Churf<ürstlichen〉Durchl<aucht〉 RentCammer, der andere helbe theil aber mir als dem autori, od<er $>$ meinen erben verfallen solte etc.

Dieweil mich aber vber verhoffen, die meist<en〉 büchführer aus lauter misgunst vndt eigennuz, dieweil sie meine musicalische sach<en〉 nicht zum verlagk bekommen, wo es ihnen nur möglich〈en〉 gewesen, gedrucket vndt gehindert, vndt sonderlich, wenn solche beÿ ihnen gesucht vndt begehret word<en〉, sie mit hintansetzung $\mathrm{d}<\mathrm{er}>$ christl<ichen $>$ liebe vndt gewissens, ganz vndt gar verleugnet, als ob sie nirgents vndt gar I [fol. $\left.77^{\mathrm{v}}\right]$ nicht zu bekommen wehren, dahero erfolget, daß dieselben mir zu mercklichem schaden vndt nachtheil meines hierauff gewendet<en〉 großen fleißes, kunst vndt vncost〈en〉, mehrer theils liegen blieben, weil ich voraus kein offenes gewelbe, darin sie ied<er»man vor aug<en〉 liegen möchten, haben kan.

Vndt haben sie die buchführer zwar solches alles nur zu dem ende gethan, daß wann die in churf «ürstlichem > privilegio determinirten zehen jahr verlauffen wehren, sie also dann desto sicherer solche meine opera entwed<er $>$ nachdrucken, od<er〉 doch zum wenigst<en〉, wann sie außerhalb landes nachgedrucket wehren (wie es dann auch nunmehr mit meinem vnüberwindlich<en> schaden zu Straßburgk von Paul Lederitz Buchhändelern daselbst<en〉 geschehen) in E<urer〉 Churf<ürstlichen〉 Durchl<aucht Land<en〉 verhandeln dörfften.

Demnach so gelanget an E<ure〉Churf<ürstliche〉 Durchl<aucht〉 mein anderweit ganz vnterthenigstes höchst demütiges bitten, Sie geruhen gnedigst mich, dero weiland vier jahr langk gewesenen vnwirdigst<en〉 capellknaben, vndt auch in vormundtschaff[t] zweÿ jahr lang Fürst<lich〉Säch «sisch〉 Weimarischen capellmeister, beÿ meiner großen mühe, fleiß vndt arbeit, weil ich sonderlich auch an itzo ein großes geist $<$ liches $>$ musicalisches opus, von allerleÿ schönen motetten vndt concertt<en〉, mit 1. 2. 3. 4. 5. 6. 7. 8. 9. $10 \mathrm{vndt}$ 12. stimmen etc. wormit [sic] verhoffentlich nicht allein hoher potentaten hoffcapellen, sond $<$ er $>n$ auch anderen stadt-kirchen vndt schulen mercklich<en〉 gedienet seÿn kan vndt wirdt, vnter handen habe, wie dann, sond<er ruhms, von E<urer〉 Churf<ürstlichen〉 Durchl<aucht〉 wolverstendig〈en〉 capellmusicis selbst<en〉 ich deßweg<en〉 geliebet vndt gelobet werde, wieder solche eigen-[fol. 78r] nüzige misgünstige buchhändler vndt nachdrucker in gnedigst<en〉schuz vndt schirm zu nehmen, vndt das mir A<nn〉o 1617. vff zehen jahr lang gnedigst ertheilte privilegium de novo, vndt zwar, weil mein vertrieb aus obangeführt<en〉 vrsach〈en〉, gar schlecht vndt gering, meinem armen weib vndt kindern nach meinem tode zum best<en〉 ad tempus infinitum zu confirmiren vndt zu extendiren. 


\section{Stephen Rose}

Solches wie es gereicht zu beförd<er〉ung des kirchen-gottesdiensts zu auffnehmung der edlen music, zu verhinderung d<er $>$ meisten buchführer großen vnersetlich<en〉 eigennuzes, vndt dann endlich〈en〉 mir vndt denen meinen, ezlich〈er`maßen zu meiner durch Gottes Gnade, vndt langwierig〈en〉 fleiß erlerneter kunst, wie auch auffgewendet<er〉 schwer fallend<en〉vncost<en〉, ergözligkeit.

Alßo bin vmb E<urer> Churf<ürstlichen〉 Durchl<aucht ich es mit meinen vnterthänig〈en〉schuldig<en〉 trewen gehorsam, zu furfallend<en〉 auffwartungen, nebenst inbrünstigem gebet fur E<ure〉Churf<ürstliche〉Durchl<aucht vndt dero churfürstliche herzlieben angehörig<en〉, ich zeit meines lebens zuverdienen, als pflichtschuldigk, so auch bereitwilligst, vndt eusserstem vermögen nach gefließen, Dat<um〉 Leipzigk, den 13. Novembr<is〉A〈nn〉o 1628.

E<urer〉Churf<ürstlichen〉Durchl<aucht〉 Vnterthenigst<er gehorsambster trewer diener, Johan Herman Schein,

Director der Music daselbst $m<a n u>p<r o>p r i a$.

Translation:

Most illustrious, high-born, most gracious Elector and gracious Lord, my most submissive and most obedient service is before your Electoral Highness, to the best of my ability.

Most gracious Lord, your Electoral Highness will remember most graciously the substance of the most humble supplication I made to your Lordship in 1617 regarding a privilege for my musical works. From your innate electoral sympathy and most gracious affection for the noble art of music and those who cultivate it with great understanding, your Electoral Highness conceded at that time to my most submissive petition, that neither booksellers nor printers should reprint my musical things (which I myself was to publish, for the reasons adduced there), for the following ten years in the lands and endowments of Electoral and Princely Saxony. Nor should the same music be printed, sold or traded in other places, under the threat of the confiscation of all reprinted copies, and a fine of 100 gold florins, half to be paid to your Electoral Highness's treasury, half to me as author or to my heirs.

But against my expectation, most of the bookdealers acted from pure malice and self-interest, because they could not get my music to publish, so it was possible for them only to suppress and impede it. In particular, when people sought and desired my music from them, they with disregard for Christian love and conscience completely denied it, as if they were never able to get my music. It hence followed that the greater part of my music lay unsold, to the notable damage and disadvantage of the great diligence, skill and expense that I expended on it, because I do not have a public shop where I can lay my publications before the eyes of anyone.

And the bookdealers have done all this only for such purpose that, when the ten years stipulated in the electoral privilege have expired, they therefore will either reprint such of my works with all the less risk, or at the least be able 


\section{Protected Publications}

to sell in your Electoral Highness's lands unauthorised reprints from other territories (as has now happened, to my insuperable harm, with copies published in Strasbourg by Paul Ledertz, bookdealer there).

Hence may my utterly submissive and most humble request reach your Electoral Highness, that you most mercifully look on me, who formerly for four years was a most unworthy chorister [at Dresden], and also for two years was interim Kapellmeister at the princely Saxon court at Weimar, with my great effort, diligence and labour; and especially because now I have ready a large work of sacred music, with all kinds of pleasant motets and concertos, with $1,2,3,4,5,6,7,8,9,10$ and 12 voices, etc., which hopefully will be of service not just to the court chapels of high princes, but also to town churches and schools; and because, without boasting, on account of this I am loved and praised by the expert court musicians of your Electoral Highness. Take me in most gracious protection against the self-interested, malicious booksellers and reprinters, and renew the privilege graciously granted in 1617 to me for ten years, and indeed - because my business for the above-named reasons is so poor and slight - confirm and extend it infinitely after my death for the benefit of my poor wife and children.

This will secure the furtherance of church worship, the advancement of noble music, the hindrance of the great, insatiable self-interest of most bookdealers, and finally gratification for me and my heirs, for my art (given to me through God's grace and learned through lengthy diligence) and also for the heavy costs I have incurred.

Therefore I stand before your Electoral Highness with my submissive, dutiful service, in constant attendance, with most ardent prayers for your Electoral Highness and your beloved electoral relations. I shall serve you for all my life with allegiance, most prompt service, and to the best of my powers. Dated Leipzig 13 November 1628.

Your Electoral Highness's most submissive, dutiful true servant Johann Hermann Schein

Director of Music at the same place, in his own hand

\section{A P P E N D I X 5}

Jakob Schuster's 1641 Application for a Saxon Privilege for the Posthumous Publication of Schein's Music

Jakob Schuster to the Elector of Saxony, 14 February 1641. D-Dla, Loc. $10758 / 01$, fols. $44^{\mathrm{r}}-45^{\mathrm{v}}$. In the hand of Daniel Heidenreich and signed by Schuster.

Durchlauchtigster Hochgeborner Churfurst, E<urer〉 Churf<ürstlichen〉 Durchl<aucht〉 seyndt meine vnterthänigste gehorsamste dienste iederzeit bevorn gnädigster Herr. 


\title{
Stephen Rose
}

Demnach ich Johann Herman Scheins, gewesenen musici vndt cantoris alhier zu Leipzigk selkig> nachgelassenen wittwen vndt erben eine ziemliche anzahl gedruckten exemplarium der operarum musicalium, als die Opella Nova oder geistlichen concerten 1. vndt 2. theil in 4to. complet, Waldtlieder, 1. 2. 3. theil complet, Cantional vndt gesangbuch in 8to, Studentenschmaus in 4to, Hirtenlust vndt Israelbrünnlein auch in 4to, so gemelter ihr respective ehewirth vndt vater Johann Herman Schein sel<ig> hinderlich gelassen, vor etlichen iahren, sampt denen darzu gehörigen kupffern, erblichen abgekauff, solche auch sindt derselben zeit dermassen abgegangen, das mir albereit eine geraume zeit hero kein einig exemplar von allen obspecificirten stücken vbrig gewesen.

Wann dann nach solchen stücken stetig starke nachfrage geschickt, ist auch von vielen ehrliebenden leuten gebeten worden, das ich doch solche anderweit wolle drucken lassen vndt wider vfflegen, zumaln, weil das erlangte Scheinische privilegium albereit am 17. Novembris des 1638. iahres I[fol. $44^{\mathrm{v}}$ ] seine endtschafft bekommen, vndt ich aus angezogenen motiven vndt vrsachen mir vorgenommen, solche wieder in 4to, das cantional vndt gesangbuch aber in 8to. 240. 180. ${ }^{157}$ vffzulegen wann hierüber ein gnädigst privilegium mir wurde mitgetheilt werden.

Als gelanget an E<ure〉Churf<ürstliche〉 Durchl<aucht〉 mein vnterthänigstes suchen vndt bitten, sie gnädigst geruhen, mir hierüber vff etliche iahr ein gnädigst privilegium mitzutheilen, damit mir kein buchhändler noch drucker solche nachdrucken vndt d<enn〉solche anderer orthen gedruckt, nicht verkauffen noch verhandeln mögen. Ich bin des vnterthänigsten gehorsamsten vndt schuldigsten erbietens, ertheiltes gnädigste privilegium, ohne E<ure〉Churf<ürstliche〉Durchl<auchtige〉 consens, niemandt zucediren, angeregte wergk fleissig corrigiren, vff fleissigste drucken, vndt gut Pappier darzu nehmen zulassen, so offt auch solche in denen privilegirten iahren vff neue von mir auffgeleget werden möchten, in E<urem〉Churf<ürstlichen〉 Durchl<auchtigen> OberConsistorium, die deswegen gehörige exemplaria vff meine vncosten einzelschicken, auch kein einiges zu distrahiren vndt zu verkauffen, es seÿn dann solche exemplaria | [fol. $45^{\mathrm{r}}$ ] schuldiger massen eingehändigt.

Solches vmb E<urer〉Churf<ürstlichen〉Durchl<aucht〉 in vnterthänigsten gehorsam zuverdienen, bin ich iederzeit ersuchen vermögens schuldig.

\author{
Leipzigk den 14 Februari A<nn〉o 1641 \\ E<urer>Churf<ürstlichen〉 Durchl<aucht〉 \\ Vnterthänigster gehorsambster \\ Jacobus Schuster \\ Buchführer in Leipzigk $m<a n u>p<r o>$ pria \\ Daniel Heidenreich concepit
}

${ }^{157}$ In the draft privilege (Loc. 10758/01, fol. $43^{\mathrm{r}}$ ) the proposed formats for the Cantionalare '8to. 12to. 18to'. 


\section{Protected Publications}

Translation:

Most illustrious high-born Elector, my most submissive obedient service is always before your Electoral Highness, merciful Lord.

The surviving widow and heirs of the late Johann Hermann Schein, former musician and cantor here in Leipzig, were left with a large quantity of printed books of music from their husband and father the late Johann Hermann Schein, namely Opella Nova or the first and second parts of sacred concertos in quarto complete, the Waldlieder [ = Musica Boscareccia $]$ in the first, second and third parts complete, the Cantional hymnal in octavo, Studenten-Schmauss in quarto, Hirtenlust [ = Diletti Pastorali $]$ and Israelis Brünlein also in quarto. Some years ago I purchased these copies, together with the respective copperplates, from the heirs. By now all these copies have completely sold out, so that already a while ago not a single exemplar of the above-mentioned pieces remained available.

Because these pieces have always been in great demand and because of the requests of many honest people, I would like to have them again printed and published, especially because Schein's privilege already expired on 17 November 1638. From this aforementioned motive and cause I have resolved to publish such [works] again in quarto, but the Cantional hymnal in octavo, [duodecimo] [and] octodecimo, and hence I wish a merciful privilege for this to be communicated to me.

Thus may my most submissive request and petition reach your Electoral Highness, that you most graciously deign to grant me for this a most gracious privilege for some years, so that no bookdealers or printers may reprint the same, nor may they sell or trade any such copies printed in other places. I am making the most submissive, most servile and most dutiful entreaty [for a] most graciously granted privilege, [so that] without the consent of your Electoral Highness, nobody be allowed to hand over [to a publisher] the aforementioned work, nor to correct it diligently or print it diligently, nor put it on good paper. Also as often as new editions of this work are published by me during the duration of this privilege, I will send to your Electoral Highness's Upper Consistory copies of the same at my own expense. Not a single copy will be distributed or sold, without such exemplars being dutifully handed over.

In most submissive service to your Electoral Highness, I am at all times bound to your bidding. Leipzig, 14 February 1641

Your Electoral Highness's most submissive and obedient Jakob Schuster, bookdealer in Leipzig, in his own hand written by Daniel Heidenreich 


\section{Stephen Rose}

A P P E N D I X 6

\section{Andreas Hammerschmidt's 1662 Application for a Saxon Privilege}

Andreas Hammerschmidt to the Elector of Saxony, 6 March 1662. D-Dla, Loc. $10758 / 3$, fol. $35^{\text {r-v }}$. Autograph.

Durchlauchtigster Hochgebohrner Churfürst, E<urer〉 Churf<ürstlichen〉 Durchl<aucht s seindt meine unterthänigste dienste stets bereit.

Gnädigster Herr, E<urer〉 Churf<ürstlichen〉Durchl<aucht> gebe ich hiermit in unterthänigkeit zu erkennen, wie daß ich ein werckgen, nahmens Geistliche Kirchen und Taffel Music, verfertiget; wann ich dann nun auf anmahnung vieler gelehrten, und der music liebhabenden leuthe gedachtes werckgen an das tage-licht zue geben und denken zue laßen willens, darunter ich nicht meine, sondern Gottes ehre und deselbigen heiligen> kirchen nutzen suche, weil aber solches werckgen ich selbsten verlegen wil und mier darzu über sechßhundert gülden unkosten nötig seÿn und ich mich also hin und wieder in schulden stecken muß, so stehet mier dieses in wege, es möchten sich eigennützige leuthe finden, welche dieses mein werck nachzudrucken und zue verhandeln, sich unterstehen und belieben laßen möchten, dardurch mier meine große arbeit nicht allein zue wasser gemacht sondern auch ich ins euserste verderben gesetzet würde.

Gelanget derowegen an E<ure〉 Churf<ürstliche〉 Durchl<aucht〉 mein unterthänigstes und fleißiges bitten, sie geruhe gnädigst mein darüber sonderbarer begnadigung und privilegium ertheilen zuelassen, damit niemandt, es seÿ auch wer er wolle, solche meine arbeit werden einzeln, noch zue andern sachen gedruckt, noch auf ander art und form, wie dieselbe I [fol. 35 ${ }^{\mathrm{v}}$ ] auch seÿn möchte oder könne, beÿ hoher pöen und verlust aller exemplarien, auf zehen jahr lang, doch ohne maaß geben, nachzudrucken, distrahiren und zuvertreiben, ohne meinen und der meinigen consens, sich gelüsten laßen solle. Solcher mein angewendeter fleiß gleich wie derselbe aus intention gemeines nutzens hergefloßen, also werden E〈ure Churf<ürstliche〉 Durchl<aucht diesem meinen unterthänigsten petit[i]o[ni] gnädigst statt geben, welches üm E<ure Churf<ürstliche〉 $\mathrm{D}<$ urc $>$ hl<aucht , die der Allerhöchsten mitt guter leibes gesundheit, langen leben und glück und friedlichen regierung gnädigst seegnen $[s i c]$ wolle, ich in unterthänigkeit zuverdienen stets gefliessen bin. Datum Zittau am 6 Martij A<nn〉o 1662.

E<urer> Churf<ürstlichen> Durchl<aucht>

Untherthänigster

Andreas Ham $<\mathrm{m}>$ erschmiedt

Organist daselbsts 


\section{Protected Publications}

Translation:

Most illustrious high-born Elector, my most submissive service is prepared for your Electoral Grace.

Most merciful Lord, I submissively give your Electoral Highness to know that I have completed a little work, named Sacred Church and Table Music; and now, at the encouragement of many learned and music-loving people, I wish to be able to bring this aforementioned work to the light of day, through which I seek not mine, but God's honour and the benefit of the Holy Church. But because I wish to publish this little work myself and will for this purpose incur expenses exceeding 600 florins, and I must therefore myself go back and forth into debt, so there is this obstacle standing in my way: there might be selfish people who themselves would dare and delight to reprint my work and sell it, through which not only my great labour would be turned to water, but also at the worst I would be ruined.

Therefore may my most submissive and diligent petition reach your Electoral Highness, that you deign to grant most graciously my special favour and privilege, so that nobody, whoever he may be, should take pleasure in printing, disseminating or selling my work, either singly, or printed with other things, or in other styles and formats, whatever they might be, without my consent or that of my heirs, at the threat of high penalty and the loss of all copies, for a period of ten years without restriction. For my expended diligence, which flows from an intention of [serving] the common good, therefore will your Electoral Highness graciously grant my most submissive petition. To your Electoral Highness, who the Almighty will graciously bless with good health, long life, and a happy and peaceful reign, I stand in humble service. Dated Zittau, 6 March 1662.

Your Electoral Highness's most humble servant Andreas Hammerschmidt, organist at Zittau. 
